\title{
Đivo Bašić
}

E-mail: divo.basic@dumus.hr

Dubrovnik Museums, Maritime Museum, Tvrđava Sv. Ivana, 20000 Dubrovnik

\section{Shipping in Dubrovnik between the fifteenth and seventienth centuries}

\begin{abstract}
The maritime and land trade of the City of Ragusa (Dubrovnik) and its surroundings has always been "the corner stone" on which the grandeur of Dubrovnik, its political and economical power and culture were built. As early as 1441 , the Dubrovnik trade was considered to consist of $3 / 4$ of the maritime and only $1 / 4$ of the land based trade. In 1181, the comunitas ragusina - the Commune of Ragusa was mentioned for the first time; as the time went by, it became the City-state. It was named The Ragusan Republic in 1430. The treaty concluded with Turkey in 1442 was in force up to the twilight of the Dubrovnik Republic (1806). It was convenient for Ragusans to have a sole ruler and a single state in their neighbourhood, not to mention how stubborn and quite often wanton ones. In his work "Mari, Golfi, Isole, ..." (1688.), Vincenzo Coronelli, the mapmaker, said about the Ragusans: “...They are the most ardent defenders of their freedom, putting in a great deal of effort to secure it, and at the same time, hating any kind of slavery...". The Ragusan vessels were attacked by the pirates from Rhodes from 1507-1509 and later on. The main reason for flourishing of Ragusan shipping and trade was based upon focussing on their public life within these domains. The Ragusan Republic depended upon its investments into maritime affairs and assistance offered through stimulations, interaction of processes and consequential strengthening of its own prosperity (its enriched citizens). The Ragusan Maritime Insurance Law (Ordo super assecuratoribus) of March $5^{\text {th }}, 1568$ is the oldest enacted law in the world, and in this way it was more than a century older than legal regulations on the maritime insurance - Ordonnance de la marine of 1681. Apart from the main shipyard in the old City port (in portu interiori Ragusii, in portu Ragusii), up to the construction of the new shipyard in Gruž (1526) there were shipyards in Ston and in the nearby islands of Lopud, Šipan (in Suđurađ) and Koločep (Kalamota) already in the $14^{\text {th }}$ century. Palladius Fuscus (1450-1520), in his work De situ orae Illyrici (published posthumously in 1540) cited that "there was no such a secluded part of Europe or one so inaccessible to the newcomers, where you would not encounter Ragusans practicing their merchant activity". According to some researchers, Ragusa was the third strongest force in the Mediterranean (after Genoa and Venice) in the $14^{\text {th }}$ century. The Ragusan Republic was the first in the Mediterranean in the $16^{\text {th }}$ century and, in terms of their trading ocean-going sailing vessels under Ragusan and foreign flags, it was the third in the world (after Spain and the Netherlands). In his work Nautica Mediterranea (Rome, 1602, pp. 4-5), Bartolomeo Crescentio said: “....among experts and master craftsmen for galleons are the most numerous, and the most capable in this (the Mediterranean Sea, observation of the author) are Ragusans", and Pantero Pantera in his work L'Armata Navale (Rome, 1614, p. 66) wrote down: "...while for navas and galleons building, masters of Dubrovnik, Portugal and England were highly esteemed"."Argosy", in fact, means "a Ragusan ship". Many endeavours and achievements in the art of shipbuilding raise the East Adriatic coast above the West one, since it had most frequently been a successful way in which ships and men reached different parts of the world.
\end{abstract}

Key words: Shipping, Dubrovnik (Ragusa), Republic of Dubrovnik (Ragusa), Republic of St. Blaise, The Ragusan Maritime Insurance Law 
From the human point of view, the sea is, except for the eternal ice (and deserts), the most hostile environment in the biosphere. The sea is not an ordinary or the "natural" human place of abode, thus it plays a trick on all those locked up by the obvious. On our planet, the land is marginal in comparison with the sea. Many great civilizations usually taken as continental totalities are more easily understood if transformed into the maritime ones. The call of the seas was not a universal feeling, but global history has become a reality emerging from the maritime history. ${ }^{1}$

The Old Ragusans created a well organized state with precisely defined rights and duties, in order to have their community, established and maintained for the sake of being utilitarian and for the prosperity of the whole, protecting itself from the extreme consistency (consequences). Each legal act of the Ragusan Government and citizens would confirm that the citizens and the state were a single whole. The Ragusans travelled around and circumnavigated the globe "like bees", as the Ragusan Government said, and accumulated wealth from all around the world (in their large houses ${ }^{2}$ of the small and modest Ragusan Republic).

Throughout its entire history, "its source of life, grandeur and freedom", and by its nature the sea has always been of a multinational significance and policy. The maritime and land trade of the City of Ragusa (Dubrovnik) and its surroundings has always been "the corner stone" on which the grandeur of Dubrovnik, its political and economical power and culture were built. As early as 1441 , the Dubrovnik trade was considered to consist of $3 / 4$ of the maritime and only $1 / 4$ of the land based trade. ${ }^{3}$

In 1181, the comunitas ragusina - the Commune of Ragusa was mentioned for the first time; as the time went by, it became the City-state. It was named The Ragusan Republic in $1430,{ }^{4}$ yet the Venetians, their competitors, continued to call it the "commune". ${ }^{5}$ (1797.)

It is interesting that slave trade was abolished in Dubrovnik in $1416 .{ }^{6}$ It was already in 1413 that the Consilium Minus - The Small Council forbade the slave trade; the residents of the island of Korčula restricted the slave trade in 1378 and repeated the ban in 1418. ${ }^{7}$ Ivan, the Russian, called Janji, came before the rector Nikola Gučetić in 1447 , led in chains as a slave to a Catalan merchant, asking his liberation in Dubrovnik, "the free City" since he was kept prisoner as a shipwrecked person by the Catalan.

\footnotetext{
Fernández-Armesto 2008: 8-9, 20, 30.

Tadić 1928a: 8-9.

Cvjetković 1928: 20-21, 27, 30.

Mitić 1987: 487-489, 492.

Mitić 1976: 65-69.

Lučić 1988a: 93, 100; Lučić 1991d: 516, 529. In the Statute of the City of Ragusa (1272.), in Book VII (which is entirely dedicated to shipping), chapter XIX reads: "Slaves sailing as sailors on board Ragusan sailing vessels are to sail as freed-men". See: Statut grada Dubrovnika 2002: 384-385; Statut grada Dubrovnika 1990: 199, 422; Sundrica 1972: 26.

7 Vinaver 1953: 127.
} 
Salesmen and buyers of black slaves in Ragusa were the Catalans, the Siracusans, the Florentines, the Greeks and others (settled in Ragusa), and the average black slave price was 30 ducats. ${ }^{8}$ The majority of slaves bought in Greece or in The Ottoman Empire were usually from Russia or Tataria [ex-Tatar USSR] while those from Egypt were either Arabs or Negroes. ${ }^{9}$ In his work “Mari, Golfi, Isole,...” (1688.), Vincenzo Coronelli, the mapmaker, said about the Ragusans: “...They are the most ardent defenders of their freedom, putting in a great deal of effort to secure it, and at the same time, hating any kind of slavery...". 10

Between 1406 -1408, out of thirty-six clerks in Senigallia there were fifteen Ragusans, Bosnians, Sclavi. In the Italian Marches, there were also boatmen, and also a certain "Barbarossa raguseo", patron of the ship (Ital. burchio) owned by Pandolfo Malatesta (1409-1410). ${ }^{11}$

Some people from the Croatian Adriatic lands were taken as prisoners to North Africa, while some were converted to Islam, later to become pirates. Sometimes these were the very Muslims to help (financially) their own fellow citizens to liberate themselves from slavery, dispatching letters or money to their families back in their homeland. They were usually slave redeemers (envoys) from different parts who travelled from Sicily and Malta, buying off slaves in the presence of witnesses, merchants, seafarers, foreign consular representatives or the Catholic missionaries. ${ }^{12}$

There was a pirate ship from Syracuse (46 crew members) that looted some Ragusans during the spring of 1431, which made the Ragusans dispatch their war galleys in pursuit of them and later on report them to the authorities in Syracuse. In the Ragusan territorial seas, there were pirating the French (from Provence), as well as the Spaniards, Italians, Greeks (from the Aegean islands), Turks, Albanians and others. The Ragusan Republic war galleys used to be ready at sea from spring until late autumn, while in the wintertime they were kept in the shipyard arsenal in the old nucleus, where the military ovens were still in existence in 1929. In October 1510, a Spanish vessel arrived at the port of Ragusa from San Sebastian (the Bay of Biscay), loaded with fine fabrics brought from England, via Messina, for merchants of Ragusa. In the port of Zaton near Dubrovnik, they were attacked by seven Turkish ships that had closed the entryway to the bay and opened gunfire (October $\left.26^{\text {th }}\right)$, as the men from the Biscay had persistently rejected to surrender, while the Turks unloaded several bombard-guns for easier and more precise shelling. The Ragusan Senate discussed the issue for three days, while the two noblemen tried to deflect the Turks from their intention of capturing them. After the surrender of the men from Biscay, the Turks took

\footnotetext{
$8 \quad$ Vinaver 1955: 437-438, 440-441. Nevertheless, text mentions black slaves in foreign ports whose commercial mediators are some Ragusans.

9 Carter 1972: 240.

10 Škrivanić 1960: 200.

11 Anselmi 1976: 9-10.

12 Tadić 1937a: 360-361.
} 
their loot since they had not succeeded in their negotiation with the Ragusans over the price of buying off the ship and her cargo. The captured sailors (forty-two of them, some wounded) remained in Zaton, helped by Ragusans who gave them directions to their homeland across the Italian peninsula. The owner of the Biscay vessel accused some Ragusans, and it was during the dispute that their attorneys came to Dubrovnik on two occasions, and so did the owner's son. The King of Spain also intervened, and it was some 20 years later that the claim for compensation was dropped. However, a Ragusan vessel was seized on her voyage from England in the Bay of Biscay and was sold with her entire cargo on her voyage from England, and another one near Sicily. Don Pedro Bovadila, a Spanish pirate, seized two Ragusan ships in the Ionian Sea in 1516. His reappearance and pirating in the spring of 1517 urged Ragusans to prepare two galleys and two armed merchant ships (under the command of Miho Bona) in pursuit of him to Crete and Malta. The Ragusan authorities reprimanded Miho Bona at the end of 1517 for his failure to catch Bovadila who had captured another Ragusan vessel in Zante during the summer. Ragusans hanged seven pirates who were captured during the raid against Bovadila on July $24^{\text {th }}, 1517$, since it was the custom of the time to be strict with pirates. In addition, twenty more pirates, captured subsequently met the same destiny upon the discussion held in the Ragusan Senate on August 27 1517: four of them were imprisoned, six were hanged, and ten were chained around their necks with stone weights and thrown into the deep seas. Ragusans have put on award for Bovadila's assassination (a house in Dubrovnik in the amount of 2.000 ducats and a lifetime pension of 6 ducats a month). They intervened before Pope in order to prevent the knights from Rhodes to come to Bovadila, but pirating had its primeval looting drive. Ragusans put on another award, for certain friar Ivan who was pirating in 1518. An armed bireme from South Italy was pirating around Dubrovnik in July, 1518. A Greco-Turkish ship that entered the Bay of Slano during the night of June $16^{\text {th }}$, 1518 was attacked and taken by pirates that looted and abandoned her in the open sea. The Mljet authorities informed the Ragusan authorities on an empty and abandoned ship floating in the vicinity of their island, so the Ragusan authorities decided on her secret sinking or setting on fire in case of possible Turkish capturing. An escaped prisoner from Abruzzo on the Italian peninsula was Uluzaliban (thus called by Andrija Kačić Miošić); in August 1571, he attacked Korčula, looted Hvar and Starigrad, and some other settlements on the island of Hvar and participated in the Battle of Lepanto (October $7^{\text {th }}, 1571$ ). Ragusans paid ransom for many imprisoned Croats from Dalmatia and held children of unknown appurtenance in their homes. Dubrovnik had even then demonstrated its Samaritan face of slave redeemer, the fact that had been earlier eternalized by the poet Hanibal Lucić (1485 -1553) in his work "The Female Slave". ${ }^{13}$

After 1505, all navas sailing to Alexandria were armed. In addition, the Ragusan Senate decided to inform "Ragusan vessels and merchants in Alexandria about the ar-

Tadić 1929e: 250-253. 
med ships in the East" in 1506, that the cargo of spices carried aboard the nava owned by Miho, son of Stjepan (from the island of Lopud), loaded in Alexandria, was looted. The Ragusan vessels were attacked by the pirates from Rhodes from 1507-1509 and later on. The Ragusan authorities planned to send a military raid against Don Pedro Fernandez Bovadila, the notorious pirate from Rhodes (triremes and armed navas) under the command of Nikola, son of Frano from Šipan (whose nava was seized by Pedro's galleon in the Levant), but on May $11^{\text {th }}, 1517$ this was ordered to Miho Bunić, the flotilla commander, who received 2.000 ducats for premiums to captains and an additional present. After a number of inconveniences, it was only in 1519 that the peace treaty was concluded between the Ragusan Republic and the pirates of Rhodes. ${ }^{14}$

At the beginning of the $2^{\text {nd }}$ decade of the $15^{\text {th }}$ century, Ragusans delivered lead, leather, and other merchandise to Sicily and Sardinia, especially lead oxide to Hydrunt (Otranto), and they imported salt from Trapano, oil from Hydrunt and wool from Siena. Grain, wool and currants (uva passa, zibibi) were imported from Patras, as well as grain from Arte. They exported currants from Corfu to Senj or Rijeka, fave beans were delivered from Hydrunt, salted pilchards and salted eels were exported to Sicily (Syracuse). Lead, lead oxide and timber (bought in Senj) were exported to Palermo and Trapano, while salt was imported from Sicily. Ragusan vessels transported soap, cloth (pannos), honey, oil, poppy (paperum), silver, kerseys, corals, lead oxyde to Alexandria in 1512, and brought over ginger. Alum, lead, lead oxide, supraman cloth (de santo Martino) was unloaded in Beirut. Cotton (cum onere gottonum) and leather were imported from Constantinople, and zambellotus - camel or goat hair cloth from Adrianople for merchants in Florence. Cibet fur was exported to Rome from the towns located in the western part of the Italian peninsula, and they delivered lead, lead oxide and sumach timber (scotanum) in Leghorn (Livorno). They transported grain and oil from Molfetta to Pisa and Venice. Ragusans used to buy special white lamb's pelt in Nuceria (Campania) and their ships were loaded with grain and silk from Patras. They exported white wax to Naples for the needs of St Severin's monastery (customs duty exempted). Ragusans delivered lead and lead oxide in Beirut, and from there they imported salpeter (cineres). Silk, zambellotus - camel or goat hair cloth and other merchandise was sold in Brusi. Oil, almonds and lead were exported to Constantinople. During the voyage, they happenned to be attacked by the pirates of Rhodes. ${ }^{15}$

In the first half of the $15^{\text {th }}$ century, silver and lead were especially exported to the ports of the Mediterranean, via and from Dubrovnik, as well as to Barcelona and other towns on the Pyrenean peninsula, since Catalans were not strictly obliged to concentrate on their native area. A Trading zzSociety (societas) which dealt in trading with fabrics, wax and silver in Hungary, was managed by the Ragusan Grgur, son of Sabo Pucić

\footnotetext{
14 Hrabak 1956: 80, 83, 89.

15 Lučić 1977: 358-359, 361; Lučić 1991a: 236-239, 242.
} 
(Gergus Savini de Poça) and Berlingerius from Barcelona in $1341 .{ }^{16}$ The resident of Dubrovnik Johannes Ferer from Barcelona in 1422 and the Catalan Bernardus Guasquillus invested (374 hyperperi) in the company dealing with corals which were transported to Syria, Beirut, Damascus, Alexandria and elsewhere, as recorded in $1431 .{ }^{17}$

During some years in the $16^{\text {th }}$ century, Ragusans exported several hundreds of barrels of salted pilchards to Venice; it was in June 1572, that 30.000 pounds of salted pilchards in small barrels were shipped to Venice. Apart from salted pilchards, tuna and salted bullet tuna were shipped to Ancona. In October 1552, caviar was shipped from Constantinople (Pere) via Ancona to Florence in the value of 200 ducats. A Ragusan merchant from Pere shipped as much as 21 barrels of caviar to Dubrovnik to merchants of Ancona (records of 1588). A fisherman from the island of Kalamota and the noblemen of Ragusa, Vlaho Sorkočević (Sorgo) made an agreement in February 1519 for a duration of two years, during which the former was supposed to extract corals, while the latter was to sell them (at the price of 19 ducats per centinarium with $10 \%$ of the selling price). The coral selling market was primarily in Alexandria and in the Italian peninsula. ${ }^{18}$ In a dispute entered against an importer of the Apulian lambswool in Dubrovnik in March 1582, the Ragusan Government protected interests of its leather craftsmen. In compliance with the agreement of December 1574, a Ragusan exporter and two Greek merchants from Ljes were obliged to bring "1000 good ramskins with the entire fleece" from Albania at the price of 7.5 Turkish aspre a piece. A cargo of "ramskins with fleece" shipped to Venice from Constantinople in 1594 was insured at the value of 1137 ducats. Merchant of Dubrovnik shipped to Venice 2500 tanned lambskins and 140 linings in various colours in August 1587. The cargo of thirty buffalo skins, one deerskin and sixteen badger pelts (pelles tosonorum, cu[o] te di tasso) for the Lanciano fair was insured by Petar Dragojević in June 1597. The cargo containing fifteen bales of fox pelts (pelle di volpe) was shipped to Ancona at the end of June 1551. The cargo of deerskin for the annual fair in Lanciano was insured for the amount of 100 ducats in August 1540. As many as 150 fox and ten pieces of raw marten furs (martes foina, martora) were sent with a cargo to Venice in March 1504. Chamois leather a refuso ( 8 bales and 14 pieces) was shipped from Dubrovnik to Venice in 1538, while in November 1570, another cargo of furs composed of 357 pieces of wisent ${ }^{19}$ was shipped from Dubrovnik to Ancona. Ragusan merchants exported Bulgarian wool, hides and fine chevreau leather from Constantinople to Venice in the amount of 230.000 ducats $^{20}$ in 1550.

The treaty concluded with Turkey in 1442 was in force up to the twilight of the

\footnotetext{
$16 \quad$ Tadić 1971: 38; Hrabak 1980: 74-75; Manken 1960: 368.

17 Krekić 1961: 294, No. 790.

18 Popović 1988a: 41-44.

19 Popović 1988b: 45-46, 48, 50-52.

20 Carter 1972: 369.
} 
Dubrovnik Republic (1806). Sultan Murad promised them, in accordance with freedom of movement and trade, that he would allow them to conduct trade according to their own laws and that he would accept "people of all languages at sea and on the land" without charging any customs duty or income tax, yet only in the place of sale, solely for the goods sold. Initially, Ragusans had to give sultan "a present" of 500 golden ducats per year. It was convenient for Ragusans to have a sole ruler and a single state in their neighbourhood, not to mention how stubborn and quite often wanton ones. Thus, the merchandise from the Italian peninsula (Venice and Florence) and from France, Spain, England (London) was placed in the eastern market (Turkish) by Ragusan vessels, via Ragusa. Ragusa acted nearly unrivalled in the course of the $15^{\text {th }}$ and $16^{\text {th }}$ centuries. A great Turkish demand for fabrics gave an incentive to Ragusans. As early as in 1401, Ladislas of Naples' (6 galleys) fleet attacked the territory of Ragusa for Ragusans sided with Sigismund, and it was then that Ragusans defeated Neapolitan galleys. Sigismund assigned them to administer the islands of Brač, Hvar and Korčula (1413 -1417). Although he primarily resented Ragusans, the Pope allowed them trading with "infidels" in his bull Coena Domini which reads: "To the City of Ragusa lying at the seaside on a hard cliff and in a barren area, and for this reason exposed to the heavy seas, being very loyal to the Holy Roman Church and being fully obedient, always and permanently faithful to the Hungaro-Croatian king, is permitted to send its vessels to the areas of the Holy Land and to the ports of the "infidels", to transport pilgrims and be engaged in trade; to install consuls there, erect churches, to put up graveyards...". Papal Privilegium navigationis to the Levant and Africa had been the fate and the basis of the rise and flourishing of Ragusa. ${ }^{21}$

Upon the Venetian conquest of Dalmatian cities (1409), the territory of Ragusa was spared, but Ragusans have armed themselves and were vigilant. Venetian rule ordered the Venetian captain of a gulfo: "Do not touch those from Ragusa, their vessels and estates, but treat them in a friendly way". Upon the conquest of Dalmatia (1420), all trade was directed towards Venice, what indirectly favoured the Ragusan trade and shipping. In order not to contribute to the growth of the Ragusan merchant marine and its navy by these provisions, the Venetian Republic satisfied the demands of Dalmatian towns and mitigated the previous provisions. Ragusans were able to sail throughout the Venetian state on unarmed vessels and to import and export any kind of goods (except for fabrics and forbidden goods). By decision of Venetian authorities (July $27^{\text {th }}, 1452$ ) Ragusans could freely carry on trade between Apulia and Dalmatia, while other Dalmatian towns were subject to many constraints which contributed towards an almost complete interruption of trade transferred into the hands of Ragusans. After the fall of Bosnia (1463), Venetians had intentions to support Dubrovnik in case of Turkish attacks, thus on June $17^{\text {th }}, 1463$ (although, only briefly) they discontinued the ban of export of food from Albania to Ragusa, and as of July $1^{\text {st }}, 1463$ commanders of

$\overline{21}$ Antoljak 1944a: (9). For temporary Ragusan rule at islands Korčula, Hvar and Brač (1413.-1417.) see: Foretić 1980: 176-177. 
Venetian galleys were ordered to be around Dubrovnik and come to their assistance if attacked by Turks. ${ }^{22}$

Ivan Lucius, a historian, quoted that Dubrovnik did not come under the Venetian rule in the period 1409 -1420 (as other Dalmatian towns did) as, according to a certain Ragusan chronicler (un cronista raguseo), negotiations were conducted and the nonaggression pact between Venice and Dubrovnik was signed, so the Venetian admiral Loredan did not dispose of military forces and war galleys necessary to attack Dubrovnik on a larger scale. A humanist of Trogir, Koriolan Cipico (1425 -1493), "praised Dubrovnik as a Dalmatian city in which culture and well-being flourished". ${ }^{23}$ A larger number of merchants from Dalmatia were attracted by the market of Dubrovnik through economic advantages which aimed at placing their goods through connections and acquiring raw materials from the Balkan hinterlands, thus avoiding Venetian blockade of Dalmatian towns. ${ }^{24}$

Regarding the conflict between Kotor (under the Venetian rule) and Grbalj (nowadays in Montenegro), at the end of the third mutiny of Grbalj (1448-1452) and the ruthless Venetian pacification, it was recorded that ships of Dubrovnik and Budva transported the refugees from Grbalj to Puglia (Apulia), while the rest of the local population came under the authority of the then imposed Venetian rule in Kotor. ${ }^{25}$

Communes in Dalmatia of the $15^{\text {th }}$ and the $16^{\text {th }}$ century were faced with a threefold economic situation, not only as a consequence of Venetian and Turkish factors, but also depending on their natural conditions and economic circumstances (the basis of their economic life). Those characteristics of manufacturing, their area, location and the role in vertical and longitudinal Adriatic connections were mutually determined as "the true results of Venetian constraints and the consequence of Turkish devastations". Venice forced upon an additional customs duty of $10 \%$ on imports of Ragusan fabrics to Venetian territories, due to the simultaneous growth of Ragusan manufacturing of fabrics, as protective measures for their own silk manufacturing manifested in 1457 through the ban of imports of raw silk from Venetian mainland - terraferma unless it was previously brought and cleared through the customs in Venice. ${ }^{26}$

The main reason for flourishing of Ragusan shipping and trade was based upon focussing on their public life within these domains. The Ragusan Republic depended upon its investments into maritime affairs and assistance offered through stimulations, interaction of processes and consequential strengthening of its own prosperity (its enriched citizens). Ragusans supplied Ferrara during the war between Venice and Ferrara (which was assisted by Spain). Although they took into account the protection of the

\footnotetext{
22 Antoljak 1944d: (9).

23 Lučić 1991: 362, 370.

24 Voje 1977: 382.

25 Milošević 1977: 275, 299.

26 Raukar 1977: 212-213.
} 
Neapolitan fleet, during an attack the Venetian fleet pushed out the Neapolitan one and seized 30 Ragusan ships which were set on fire (1484), deprived of their shipload of food. ${ }^{27}$ As the entire south coast of the Western Adriatic Sea as well as the shores of the Ionian Sea were under the Kingdom of Naples, Dalmatian towns were supplied with grain from those parts. The previous war between Venice and Turks (1463-1478) had already exhausted Venetians at the annual expense of more than a million ducats. ${ }^{28}$

A classical example of the Venetian slyness is reflected in the Order of the Venetian Senate received by the General Providore at sea on September $21^{\text {st }}, 1617$, where it was stated that Dubrovnik would be subject to devastations and at the same time that it would be pretended that Venetians would favour it. Venetian authorities dispatched a letter to their consul in Ancona on March 23 $3^{\text {rd }}$, 1623: "We have been informed by reliable persons that Ragusans do not quarantine hide and other goods arriving from Bosnia and from other parts of the Turkish state with due care required". The Venetian Republic kept seizing Ragusan vessels transporting salt across the Adriatic Sea since 1626. Nadal Donato, Providore of the Armada, seized a Ragusan ship on August $26^{\text {th }}, 1626$ and took her to Venice. Upon the intervention, and to the surprise of the Ragusan Government about such a procedure, the Providore replied that Ragusan vessels transporting salt were not stopped, merely because they were not met by the Venetian galleys, since for such a matter a permit issued by the Magistrate of Venice was required. Pisani, the General Providore was ordered to stop each Ragusan vessel transporting salt to the Neretva River or elsewhere. The Venetian Republic ordered jettison of foreign salt (primarily the Ragusan one) transported across the Adriatic Sea on June $28^{\text {th }}, 1629$ in order to ban transportation of this kind. Venetian authorities ordered intercepting of Ragusan vessels loaded with the caravan merchandise already in 1627 and their forced directing to Venice, in accordance with their previous Turkish caravan redirection towards Dubrovnik (originally sent to Split). ${ }^{29}$

The Consilium rogatorum - the Senate of Ragusa decided in 1640 that nobody was supposed to transport salt or carry out salt trade unless permitted by the Ragusan Senate (from any part of the globe) into the area between Split and Valona under threat of punishment in the amount of 500 ducats or (due to insolvency) a year "in leg irons in one of those prison cells facing the open sea" (Rector's Palace in Dubrovnik), while a nobleman could be additionally deprived of his title and his voting rights for a duration of five years. From a boat or other ship that turns a deaf ear to this provision, salt was to be thrown into the sea, patron would be punished by scourging with naval thick-rope knotted end whip thrice in public and yet one year in leg irons in a prison cell facing the open sea, so that each sailor of the said vessel could be scourged with a whip, and

\footnotetext{
$27 \quad$ Novak G. 1950: 55, 59; Novak G. 2004b: 149.

28 Novak G. 2004a: 14.

29 Antoljak 1944c: 10.
} 
six months imprisonment in one of the aforementioned prison cells. ${ }^{30}$

Ragusans had the privilege to trade with Egypt and Syria in the beginning of the $16^{\text {th }}$ century when Venetians and the Genoese withdrew from these lands. From the $15^{\text {th }}$ century onwards, ship deadweight was calculated in Dubrovnik in Neapolitan manner - in carro (carro - a wagon), i.e. a unit for grain (wholesale). One "carro" held between 18 2/3 - 19 of Ragusan "staria", a Ragusan star which came to more than 111 litres. Carracks were vessels of 700 carri, galleons between 500-700 carri, and "navas" between 200-500 carri. The largest Ragusan vessels were three-masted and their deadweight was 1.300 carri (27.500 hectolitres or 9.240 register tons). Some Ragusan historians recorded that in the last quarter of the $16^{\text {th }}$ and the first half of the $17^{\text {th }}$ century some 178 ships were wrecked in Spanish service. Some (non-contemporary) writers mentioned that Dubrovnik possessed "circa 300 ships" (around 1450). A Venetian source from 1555 cited that there were fifty large ships with a mast-top in the Ragusan Republic, apart from those of smaller deadweight, and circa 5000 sailors. Beside captains (nauclerius) - commanding officers on board, there were captains by trade and by their experience and knowledge of the sea and coasts. The Ragusan Government confirmed a scribe (scribanus) under oath on every Ragusan ship sailing to foreign lands, who was in charge of law enforcement, loading and unloading, hiring sailors, decision making on objects which were subject to jetisson into the sea during storm, etc.; a scribe on ships exceeding forty milliaria deadweight had to be a nobleman ever since 1462. A minimum number of sailors on ships was precisely prescribed, so that ships of 20-30 milliaria deadweight were supposed to have eight sailors on board, those between 30-50 milliaria deadweight 10 sailors, and those between 50-80 milliaria deadweight 14 sailors on board, and for larger ships the minimum number of sailors was stipulated by the Senate. ${ }^{31}$

The Ragusan Maritime Insurance Law (Ordo super assecuratoribus) of March $5^{\text {th }}$, 1568 is the oldest enacted law in the world, and in this way it was more than a century older than legal regulations on the maritime insurance - Ordonnance de la marine of 1681. ${ }^{32}$ The law named "The Maritime Order" was in existence as early as in 1511, while the second most important law in the $16^{\text {th }}$ century in Dubrovnik was "Ordo marinaritie" (1535). ${ }^{33}$ In the summer of 1577, on navas Santa Maria della Grazia (patron Kristo, son of Nikola Naoković) and Santa Maria della Grazia (patron Marko Bianco [Bijelić]), the commercial merchandise was insured from Egypt to Sicily, Leghorn and Genoa, and the respective agreements foresaw that the premium of $12 \%$ was to be contracted throughout the entire voyage from Damiatta to the northern part of the Tyrrhenian Sea where payment was agreed upon "in instalments per miles" (a rata delle

\footnotetext{
30 Marinović 2005: 345-346.

31 Antoljak 1944b: 9.

32 Marinović 1968: 21-22. For that Regulation of insurers (Ordo super assecurationibus) see: Marinović 1981: 12, 15-16; Marinović: 2005: 260-261, 303-304.

33 Stulli 1952: 99, 101.
} 
miglia). Silvestro Tutolini guaranteed in the amount of twenty five scudos in 1573 and 1574 for the three smerigli-guns and four muskets (with gunpowder load) of a smaller nava-navetta owned by Rade Veselić (Rado d'Allegretto). Luka Ivanov Orebić insured six bronze smerigli guns for the amount of 150 scudos) on his galleon Santa Trinita, during her voyage Dubrovnik-Venice-and vice versa. The two smerigli-guns had an insurance coverage, along these lines, of 120 ducats and 125 scudos by Marin son of Petar and Jakov Cvjetković ${ }^{34}$ of October $20^{\text {th }}, 1583$ and May $15^{\text {th }}, 1584$.

The Ragusan Benedikt Kotruljević (of the Kotrulj lineage) stated in 1464: "In general, lands become rich due to their good ports, therefore it is usually said: 'Port, pig, garden or a dead man make man rich.' ('Porto, porco, orto et homo morto fa riccho lu homo'). And it is also said: 'What one cannot find in the evening, in a maritime country it can be found the next morning.' ( 'Terra de marina, quello che non ci è la sera, se trova la mautina)". Thus he mentioned: "Barcusia are another kind of naviglii tagliati which strongly resemble caravels." These were widely used in the Slavic land (Schiavonia - in Italian this term was used for the Croatian region on the eastern coast of the Adriatic), and most of all in Dubrovnik where they originated from". ${ }^{35}$ Benedikt Kotruljević (Benedetto Cotrugli Raugeo, 1400/16 -1468/69), the renowned writer, specialized in economics, the inventor of the double entry bookkeeping, in his work "On Trade and Perfect Merchant ("Della mercatura et del mercante perfetto") or more precisely: "The Book on the Art of Trading" ("Il libro dell'arte di mercatura"), Venice 1458 (printed in 1573), in the first of the four books, in chapter X (General Rules and Order of Trade Traffic) he maintained: "Our Ragusans are very capable of being engaged in the activities of this kind, therefore I would praise them easily in this place if I did not fear that critics would object and attribute it to my love for homeland. ...Do not intend to catch every bird that flies, since many have gone bankrupt due to a large amount of trade done, and nobody from a small one. You must not risk too much in transportation by sea or by land, all at once. No matter how big a wealthy person's riches were, let him be exposed, at the most, to five hundred ducats per capita, per nava, or a thousand per large galley.". In Book One, Chapter XIV (On Insurance and Undertakers), he wrote: "regarding written agreements and articles I considered a special manner and order in Barcelona, which was immaculate". ${ }^{36} \mathrm{~A}$ dispute between Bartul Gučetić, and Mihovil \& Ivan de Roda (Johannis de Roda) was recorded at the end of 1444, when "Italian customs duty" was collected in Barcelona from a citizen of Ragusa; it was paid only and mainly by Italians (dohana italica - three denarii per pound; $1,25 \%$ of the imported or exported merchandise). In his appeal, Benedikt Kotruljević was mentioned, and Ivan de Roda collected 400 ducats in customs duty from the three Ragusans. This dispute lasted for some ten years, and the astonished

\footnotetext{
34 Tenenti A. \& B. 1985: 72, 159-160.

35 Kotruljević 2005a: 84-85, 134-135.

36 Kotruljević 1989: 153-154, 165, 199; Kotruljević 2005b: 44, 48, 64.
} 
Ragusans made a statement to the authorities in Barcelona in 1446, that they were neither Italians nor Italian subjects, but Dalmatians (Croats), by their language and position and that it was the King Alfonso of Aragon that had granted them the same privileges as to the citizens of Sicily and Barcelona, while inhabitants and merchants of Barcelona were treated the same as were Ragusans in Ragusa. The Ragusan Senate (Consilium Rogatorum) defined in 1448 that the damaged parties or their envoys set out to Barcelona by themselves with the ruling by the Queen Maria of Aragon, but without success, so Ragusans sent a letter to King Alfonso. Special customs duties were not collected from the Catalans in Ragusa. In 1443 Benedikt Kotruljević got the ruling from the Queen in Valencia in his favour (1444) that he was a Ragusan, not an Italian, and that he was exempted from Italian customs duties (naturalem civitatis Ragusie quam a notorio constat esse in provincia Sclavonie...). ${ }^{37}$

Apart from the main shipyard in the old City port (in portu interiori Ragusii, in portu Ragusii), up to the construction of the new shipyard in Gruž (1526) there were shipyards in Ston and in the nearby islands of Lopud, Šipan (in Suđurađ) and Koločep (Kalamota) already in the $14^{\text {th }}$ century. ${ }^{38}$ Following the Venetian ban of building ships larger than 2.000 staria deadweight, of 1502, and due to the rivalry of the shipyard in Gruž, the shipyard on the island of Korčula (under Venetian domination) was abandoned by 180 shipbuilders (carpenters and caulkers - marangoni e calafati) at the end of the $16^{\text {th }}$ century emigrating mainly to Dubrovnik and Italy, as recorded by the providore Christoforo Valier in $1596 .{ }^{39}$

There was a special Maritime Consulate in Dubrovnik which took notes and held hearings on naval averages and thus, there were 1,000 hearings opened "officially" (very likely there were more) in respect of averages from 1629 up to 1811 in the (greater) Ragusan territory (nowadays the records are kept in the State Archives of Dubrovnik). ${ }^{40}$ Thus, for example, Vice Vlahović's bark sank near the island of Mljet (a shipload of horses for Puglia), Capt. Marin Martinčević's galleon was wrecked near the island of Korčula (1616) on her route to Ancona, Capt. Stjepo Dubac's galleon, on her route to Ancona, had an average in 1627 in front of the Dubrovnik city walls (the shipload contained 5000 cow-hides): "You should know about the disgrace which happened here to Stefan Dubac's galleon some days ago, that had sailed out from the port and was wrecked beside the city walls, she was brought back to the port thus wrecked, but they recovered a major part of cargo", as recorded by Andrija Paoli on Dec 22nd $1627 . .^{41}$

The term "map" was used by Ragusan seafarers since the $15^{\text {th }}$ century. Thus, Mavro Vetranović (1482-1576), the Ragusan poet, wrote about a sailor and the boat,

\footnotetext{
Fejić 1983: 77-83.

Lučić 1951: 137.

Pederin 1990: 165.

40 Luetić 1971b: 35; Luetić 1960b: 215; Luetić 1979: 166; Luetić 1972: 134.

41 Vinaver 1956: 430, n. 24. Besides, capt. Stjepo Dubac transported merchandise from Dubrovnik to Ancona also from 1643.-1646. (cargo of hides/pelts and wool). See: Luetić 1964: 85-89.
} 
and mentioned compass and a map. ${ }^{42}$ In a sale contract (1318) of a barcosium, "una ciesola cum calamita" - compass in her riggings was mentioned. ${ }^{43}$ The Ragusan family Gučetić has preserved the manuscript (possibly a copy) about the astrolabe (between 1428 and 1460). ${ }^{44}$ "Navigate in Ragusan manner" is an expression characterized "as the voyage of a merchant ship, when the net profit was shared half and half between the ship and the crew, while expenses for food and beverages were calculated differently, according to the category of personnel employed on board". ${ }^{45}$

Many authors wrote about Ragusan commercial and maritime achievements. Palladius Fuscus (1450-1520), in his work De situ orae Illyrici (published posthumously in 1540) cited that "there was no such a secluded part of Europe or one so inaccessible to the newcomers, where you would not encounter Ragusans practicing their merchant activity". ${ }^{46}$ Vinko Pribojević in his work On the origin and adventure of Slavs (Venice, 1532) wrote that Ragusa near Epidaurus had been mentioned by Philip of Bergamo and that it was "a city famous for its wealth, ships and freedom, nurtured by Ragusans with their skilful diligence and strong vigilance, making all the most important decisions in all their activities in their Senate". ${ }^{47}$ Fernand Braudel, the great "master" of structuralism, said about the Ragusan seamanship: "The Tyrrhenian Sea would almost be a Ragusan lake if there were no citizens of Marseilles there (modest at first, yet grown bigger after 1570),..." ${ }^{48}$ In his report to the King (1539), Lope de Sorie, the Spanish Ambassador to Venice, said that "The King of Spain considered Ragusans as his own and (that) he would accommodate them". In the letter of Don Juan sent to the authorities of the Ragusan Republic (May $8^{\text {th }}, 1572$ ) it was said of Ragusans that " their ships were delayed so that others could not send information before them, thus the news sent from Constantinople to Spanish agents in Ragusa were belated for these were ordered to do so". 49

In the mid $16^{\text {th }}$ century, Nicolas de Nicolay pointed out: "Ragusans are proud and consider that few nations had aristocracy as was their own", and the nearby port of Gruž (Grauosa) "can accept a hundred galleys". In 1583, nobleman Jean Palerne stated that: "Ragusans are great merchants, especially in the Mediterranean where they possess more than 120 large ships (...)". The travel-writer Poullet wrote that "Turks called Ragusa ... good Venice, maintaining that it was much older regarding its aristocracy and by its monuments than the Serenissima...", M. Quiclet, the Turkish

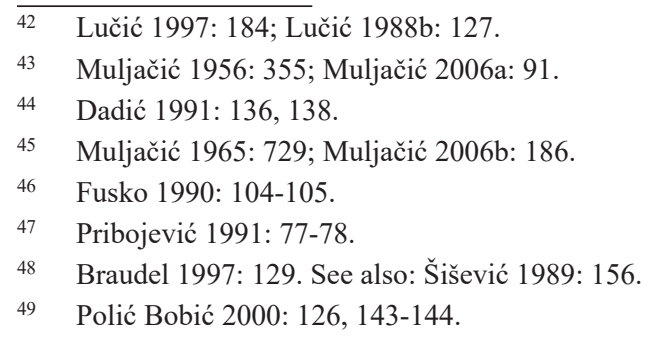


language interpreter to the King of France took notes about Ragusans on January $24^{\text {th }}$, 1658: "they are all honest people, being called Ragusans with seven banners, and also called the new Turks, for it is said that they paid them a tribute, and recognized seven foreign rulers. They are afraid of Turks, hate Venetians, like the Spanish out of interest, bear the French in awe, are very distrustful towards foreigners..." ${ }^{50}$ Samuel Pepys (1633-1703) in his "Diary" dated January $11^{\text {th }}, 1662$ said: “(...) that in a small Ragusan princedom, on the Adriatic Sea (a small state but, as they say, older than Venice, was called mother of Venice) and Turks are in its surroundings - and how they replace all officers of the guards every twenty four hours out of fear of conspiracy, so that nobody knew who the next commander of the guards would be." 51

According to some researchers, Ragusa was the third strongest force in the Mediterranean (after Genoa and Venice) in the $14^{\text {th }}$ century. The Ragusan Republic was the first in the Mediterranean in the $16^{\text {th }}$ century and, in terms of their trading ocean-going sailing vessels under Ragusan and foreign flags, it was the third in the world (after Spain and the Netherlands). ${ }^{52}$

In his work Nautica Mediterranea (Rome, 1602, pp. 4-5), Bartolomeo Crescentio said: “....among experts and master craftsmen for galleons are the most numerous, and the most capable in this (the Mediterranean Sea, observation of the author) are Ragusans", and Pantero Pantera in his work L'Armata Navale (Rome, 1614, p. 66) wrote down: "...while for navas and galleons building, masters of Dubrovnik, Portugal and England were highly esteemed". ${ }^{53}$ Experience taught us that the cut timber, specially the oaktimber, of which the ship frames were built, was of a better quality, if previously soaked in salt water. ${ }^{54}$

Foreign craftsmen were also engaged in building war ships in Ragusa (frigates, biremes and triremes). In 1416, the Ragusan authorities sent its citizen to Genoa, who was to bring over unum magistrum galearum, and in 1543,1551, 1553, and 1554 craftsmen were engaged from Naples pro fabricando ligna armata, but in 1572 the Ragusan Senate decided to have a bireme built by a local master-craftsman. Ragusan authorities sent their shipbuilders to the Ottoman Empire in 1503, 1516, 1545, and in 1547, for this was requested at Sultan's threat (ex. six caulkers were sent to Valona in 1503, while sixteen caulkers were sent to Gallipoli with the task of building the Turkish navy in 1516). In the course of the $16^{\text {th }}$ century, they asked a ship from Ragusans which used

50 Rožman-Kandido 1990: 1415-1416; 1160, 1165, 1168; Babić 1991: 20.

51 Latham - Matthews 1970: 8. in note 3 on the same page the authors quote: Luigi Villari 1904: 86-87. "Venice was in fact an older city". In fact, this is an interesting curiosity regardless of the age of these two cities and states. This information is brought in an article: Mladen Bošnjak 1952: 455. In notes 3-5, the author quoted that the subjects under discussion were the English and French translations of that "Diary" of 1939 and 1939-1940, and he also stated that it was of the same date, yet of 1661 .

52 Luetić 1994: 75; Romano 1962: 573-591.

53 Bačić 1941: 30, 32; Bačić 1948: 29.

54 Crijević Tuberon 2001: 227. 
to ship resin from Valona to Constantinople for the need of their war arsenal. In March 1512 , the obligation of master for unrigging of the old and building of a new meant a monthly salary of $31 / 2$ ducats. One of the largest Ragusan ships in the $16^{\text {th }}$ century (1.100 carri) lived to be twenty four years (1568 -1592), while two ships owned by Ragusan seafarer Miho Pracat lasted for thirty-nine (1548-1587) and thirty-six years (1565-1601) respectfully. The Ragusan ship which cost 12.000 ducats in 1567 carried 1.620 ducats worth weaponry (paid for in Venice). ${ }^{55}$

In 1517, Marin Gozze from Ragusa was promised by Master-craftsman Frano Radaković from the island of Korčula to be built a grippo (40 feet long alongside the keel, 11.5 feet wide, fore-and-aft line 4.5 feet long, and deadweight of 20-22 carri) the frames of which, tweendecks, and decks were to be made of oak wood, for an average price of approximately four ducats per carro. The following year, 1518, the same master had to build for the same commissioner two more ships in Gruž or in Zaton, one of which a two-deck sagitta (keel, 40 feet long, 13 and 15.5 feet wide) while the keel had to be built of beech timber, tweendecks of mulberry wood either from Senj or from the area of Monte Gargano, and tweendecks, the so called bastards, of oak timber either from Ljes in Albania or from Senj. ${ }^{56}$ Master-blacksmith Marin, son of Antun from Korčula, promised Frano Radulović in 1573 to bring the necessary coal for the work and all iron parts for shipbuilding to the shipyard of Gruž for the commissioner of the ship (unam navem) who was to produce iron. ${ }^{57} \mathrm{~A}$ carpenter from Korčula, Frano Martinović, with his permanent address at the shipyard of Gruž, built a ship of 80 carri deadweight, 8 fathoms and one foot per keel, 8 feet broad (towards the bow) and 4.5 feet high (height between the lower and upper deck), and the ship was to dispose of some material (technical) parts such as: the poop, castle, flooring, rudder and a boat. "If the said Ivan Martinović, patron [captain-commander of a ship] would not give the mentioned shareholders a true and correct account from one voyage to another, as written in the aforementioned ship's scrivener's handwriting, with a fair distribution of profit, in that case the shareholders themselves could depose him from command and the aforementioned Frano [Martinović] could appoint another patron [captaincommander of a ship ]". ${ }^{58}$ Ragusans would pass strict provisions (ex. in 1631 and 1632 due to shipbuilding in Korcula) for the sake of protection of their own shipbuilding activities at their main shipyard in Gruž and there were some smaller taxes imposed for shipbuilding outside Dubrovnik (eight Ragusan denarii/groschen for up to fifty carri deadweight, since 1591). Rade Kopšić and Stjepan Orebić had to pay fine for their galleons built in Korčula in 1636, for having not observed the law. ${ }^{59}$

\footnotetext{
$55 \quad$ Tadić 1949: 8-11, (note 30), 13, (note 38).

56 Foretić 1952a: 86-87.

57 Foretić 1952b: 139.

58 [Luetić] 1982: 168.

59 Foretić 1952c: 179.
} 
Nikola Sagri (Sagrojević) in his work "Comments on implementation of the high and low tide in the Atlantic" ("Ragionamenti sopra la varietà de i flussi et riflussi del Mare dell' Oceano", Venice,1574 pp. 35-37 noted that the Ragusan ships were the sturdiest in the world" and that they were built of the best wood ("Le vostre navi sono più forti di tutte le altre del mondo e di miglior legname"), so that the underwater parts of the keel did not require any repairs for ten years, while such repairs were considerably more frequent on other ships ${ }^{60}$ In William Shakespeare's play "The Merchant of Venice", at the very beginning of drama, the proud Antonius' galleys sail all around the world:

There, where your a r g o s i e s with portly sail, Like signiors and rich burghers on the flood, Or, as it were, the pageants of the sea, Do overpeer the petty traffickers, That curtsy to them, do them reverence, As they fly by them with their woven wings.

In the work by the same author "The Taming of the Shrew" and also in some others, this term is used. "Argosy", in fact, means "a Ragusan ship". The word derived from Italian Ragusea, i.e. una (nave) Ragusea, while The Oxford Dictionary gives its synonyms: ragasye, arguse, argose, rhaguse, ragosie, argosea, argosey, argozee, argosie, argosy. In The Encyclopaedia Britannica, (XIV edition, London, 1929, p. 336), under the entry "Argosy", it reads: "the original name for carrack or the merchant ship from Dubrovnik, as well as the ship from other Adriatic ports, which is used nowadays in poetry for any ship carrying precious cargo". Among the Romanic synonyms, the name used for Dubrovnik is Argus, while its inhabitants are called Araguses, as reported by the Venetian chronicler Martin da Canal in his chronicle written in the French language (Cronique des Venitiens, 1267-1275). ${ }^{61}$

The City authorities of Southampton kept under control, among others, Mihovil's of Ragusa rivalry, who made clothing articles in 1484 , so that he could only manufacture fabrics for crew member needs on galleys. Henry VIII, the King of England granted merchants Nikola Sorkočević and Federik Menčetić a permit to export 10.000 'kerseys' (approx. $150.000 \mathrm{~m}$ of woollen cloth) in 1512, and in those times two trade companies were active in London. Ragusans were settled in the London area surrounded by the Thames, Tower and Lombard Street. Some Ragusans spent the best parts of their lives along the Thames, and were buried in local churches (e.g. Matija Bobaljević was buried in St Olaf's church in Hart Street, where his sepulchral inscription was placed by Nikola Gučetić in 1567). ${ }^{62}$

\footnotetext{
$\overline{60}$ Deanović 1952: 459, 461; Mitić 1984: 6; Mitić 1985a: 59-60.

61 Torbarina 1933: 223; Putanec 1952: 171-172; Šišević 1962: 4.

62 Čoralić 2004: 62. See also: Kostić 1975: 111, 280.
} 
Miho P. Pucić's ship transported a large quantity of wine from Crete to London in 1518. The contract on loading of cargo was concluded in Venice on February $6^{\text {th }}, 1518$, and that large ship had fifty crew members. On her voyage, Pucić had to load wine for Ragusan nobleman and merchant Orsat Lukarević, who transported merchandise at his own account and risk to London. The voyage was scheduled via Candia (Crete) at the end of March, 1518 and Messina, bound for London, and by a combination of circumstances it took more than a year. On her return voyage, the ship carried fine quality fabrics to Turkey (the Levant) in spring 1519. The merchandise (fabrics) arrived from England either to Leghorn or to Messina, where transhipment onto smaller ships was possibly carried out for Khios, followed by another reloading for Constantinople and other ports. Ragusans set out their ships to Leghorn and Messina, and further on to Turkey, right after having received the news about movements of ships from England. There were several Ragusan ships on their return trip from London (loaded with cargo of fine fabrics) to Messina, Khios and Constantinople in 1524. Đivo Palmotić's ship brought 2.000 bales of fabrics to some Ragusan merchants in Messina. The Jelić's family ship transported fabrics of the Ragusan Trading Society in the amount of 600 ducats, while Valentin Sorgo transported his own goods on board a ship owned by a certain citizen of Messina. Brothers Resti lost fabrics in the amount of 650 ducats in 1524, as the ship sank on her route from England to Messina, but the value of the merchandise was paid in full, in March and April of 1525, for it was insured. The English ship "Our Lady of Mercy" (under the command of William Goysohn, owned by the King of England) transported fabrics from Ragusa to Messina in July, 1518. English merchant Guglielmus Oquales called at Ragusa to collect some outstanding debt for fabrics sent by a Florentine A. Gvidati to Frano Beneša in Ragusa. Transport of English merchandise by land to the Italian peninsula was forbidden by the Queen of England for all Italian merchants in 1557 , as she had permitted trade only by the sea route by Gibraltar. Ragusans were characterized as Italians, thus Ragusan authorities protested in writing to Niko Gučetić, to Ivan Resti and to other Ragusan merchants in London who made statement before the Queen that they were Ragusans, but not Italians "because their language was as different from Italian as was the English language, and that Ragusa was separated from Italy by the Adriatic Sea. ${ }^{63}$

Frano, son of Dživo Gradić, was one of the most significant merchants in London, Margate and Southampton in England from 1525 until around 1540 (through his own activities and those for creditors/commissioners in Ragusa, Venice and Flanders). Jerko (son of Jakov) Đurdević's family traded with England for years. ${ }^{64}$ During the $17^{\text {th }}$ century, the French tartanas, polacres and other ships were present in Ragusa, as well as some several hundred ships from the Italian peninsula and English merchant ships and seafarers. "The Maritime Consulate" (Consulatus Maris, Consolato del mare)

\footnotetext{
63 Tadić 1929b: 164-165.

64 Kostić 2007: 119, 125.
} 
was notified of as many as 355 averages during the $17^{\text {th }}$ century (maritime accidents). Some 60 English sailing ships engaged in maritime, trading and port activities called at the Port of Ragusa during the $17^{\text {th }}$ century. They were mainly bertonas and navas. ${ }^{65}$

A Ragusan vessel made several voyages from 1539 to 1545. A ship was in Venice during the summer of 1539 , following a heavy storm and damages to the mast and main sails near the Istrian coast. She was towed to Venice by smaller ships and remained there for two months for the purpose of repair and trade. The ship spent the first part of the winter in Dubrovnik and found herself in Genoa at the beginning of March 1540. After that, she sailed to Cagliari (Sardinia), Valencia, and Sicily, and back to Genoa, then to Khios in June and again to Genoa. Having transported salt from Sardinia to Algiers for the Spanish fleet, she was to be found in the service of King Charles (Carlos) V during the invasion of the Armada of Algiers in 1541. Following her probable repairs caused by damage, in August 1542, she sailed from Lisbon to Lagos (a cargo of salted fish for Naples), and then from Naples to Valencia and Palermo, and arrived to Barletta in September, 1543. After Lisbon, she set sail during a shorter voyage from Genoa during 1544, and several longer ones in 1545 (Marseilles - Naples - Palermo - Genoa - Naples - Messina - Khios). Records of expenses of that ship were recorded in Ragusa on October 1 $1^{\text {st }}, 1539$ : ship's oars bought from Zuane the oar-maker (2 ducats and 35 groschen; necessary material for the large basket ( 8 groschen); towing from the port of Gruž to Ragusa ( 2 ducats); insurance 420 ducats of credit at $8 \%$ (33 ducats and 25 groschen); Notary's record of insurance entered in the Large Book (12 groschen); for 70 pounds of powder bought by master Miho, the gunner ( 5 ducats and 32 groschen); 5 goatskins for keeping powder (10 groschen); rope for sail repair (1 ducat); 4 gunballs for the bombard-gun (2 ducats); 1 skin for hearth cover (10 groschen); for large mast, crosses, poles etc. (112 ducats and 18 groschen); customs duty of $60 \%$ on all (62 ducats and 32 groschen); repair of cauldron for coal-tar pitch (2 ducats); large anchor repair works ( 7 ducats); transportation of the large anchor to Venice ( 20 groschen); 4 barrels for water (5 ducats and 10 groschen); small barrel for powder (4 ducats); transport of crosses from Venice to Malamocco (2 ducats); to two officers, scribe and to "nauklijer"captain, for 9 months at 2 ducats a month (36 ducats); master Miho, the gunner's salary for 9 months, 3 ducats a month (27 ducats); salaries for carpenter, patron, shipbuilder and other, $11 / 2$ ducats a month (54 ducats); oil for light and wax candles during 9 months (9 ducats); a small basketful of currants given as a present to captain in Venice ( 2 ducats); a present for the small boats that towed them entering Malamocco - 2 caskets of wine ( 2 ducats); 50 pounds of dry toast as a present to the said boats (1 ducats); for exit from Malamocco (10 ducats); expenses for captain's and scribe's stay, 5 ducats a month each (20 ducats); to the lawyer to find cargo for the ship (2 ducats; votive gift to Our Lady of Šunj (Bissone) on the island of Lopud (1 ducat), etc. ${ }^{66}$

\footnotetext{
65 Luetić 1977a: 219-221, 232; Luetić 1978: 277-278.

66 Tadić 1929c: 165-167.
} 
The Ragusan Government forbade all sea captains the advance engagement of serfs to become sailors or ship's boys as of November $9^{\text {th }}, 1574$. The serf's master had to give consent to the serf to board the ship, while the ship captain had to obtain a permit from the Ragusan Senate as otherwise he was obliged to pay 300 ducats per serf or, in case he could not pay, he would be subjected to scourging three blows and 6 months' imprisonment. The Master had to report his serf to the Rector and to the Small Council if he had boarded a ship without any permit or pay a fine of 100 ducats. A fine of 300 ducats awaited the master who had given permission to the serf to board the ship without previous permit from the Senate. Informers of trespassers would be granted a third of the fine imposed. In this way, the captain reported by a serf on board would be fined for taking him on board, while the serf would receive 100 ducats. In accordance with the same ban, no Ragusan sailor was allowed to board foreign ships without permission. ${ }^{67}$

The author of the first published history of Ragusa (La Storia di Ravgia (Ragusa)) was Apresso Vincentio Busdraghi, Lvcca, 1595 - reprint; biographical and critical comments: Lodovico Ferretti; introduction, notes and a chronological addendum: G. Gelcich; Ragusa, 1903, LII, 254 [295] p.). The Dominican friar Serafin Razzi noted in his Viaggio in Abbruzzo:

"On September 11" [1577], a Ragusan ship arrived at the Vasta shores; she is said to be the largest ship, furrowing the sea and sailing over the seas - carrying the cargo of 1200 carros of grain and a crew of 140 members. ... We were shown into the main state room with carved, painted and gilded ceiling and, adjacent to it, a large salon with ceiling decorated 'with rosettes' We saw the herd of piglets and a large number of rabbits, a large number of chickens all over the ship and her holds in a secluded space under some wooden boards. There were also some beautiful cats to be seen; and also some blacksmiths and their carpenters with their respective workshops. Approximately, in the middle of the ship, under the mainmast, we saw a well with potable water, with a windlass and buckets. ...we spotted some twenty boys in another space under the deck that they call 'mali od broda'- ship's boys,... Obedience on board need not be discussed, as it is far greater than can be encountered in monasteries.... A dry toast soaked in vinegar and oil is said to be a delicacy, as it is very tasty and good nourishment for all those sailing the seas.... Such huge ships are said to cause a lot of concern and danger, but if they succeed in making one or two voyages, they pay back the entire cost of their building". ${ }^{6}$

In addition to carracks, there were more various types of Ragusan ships in opera-

\footnotetext{
$67 \quad$ Tadić 1929d: 167-168.

68 Krasić - Razzi 1999: 74-75; Krasić 1971: 26-30; Rešetar 1908: 1-2.
} 
tion $^{69}$ : galleons ${ }^{70}$, xebecs $^{71}$, grips $^{72}$, ormanica $^{73}$, small galleys ${ }^{74}$, filjugas ${ }^{75}$ (felucas) and others. The Mediterranean type of sailing vessel (pinco) was not as common in the Ragusan merchant marine, and so there were $1-4$ of them in operation in the $17^{\text {th }}$ century (100-300 carri deadweight) of a good seaworthiness and sea characteristics (similar to a xebec).${ }^{76}$ Breaking in by various pirate ships into the Ragusan territorial sea urged the Ragusan Government to set up the State Navy flotilla (brigantines, small galleys, filjugas/felucas and ormanicas) for the purpose of intervening in the Ragusan territories exposed to danger from 1645 to 1660 . Ragusan merchant ships had to be additionally armed due to attacks by pirates and hajduks. Thus, there are records of a sailing ship owned by Capt. Jako Bonfiola with ordnance of four (petriere-guns), a set of twenty loads ready for use, 10 rifles and 10 prepared loads each, 10 spears ("spontons"), 11 sabres and at least $11 \mathrm{crew}$ members. ${ }^{77}$

Ferdinand Magellan's voyage around the world was later described by the leader of the same expedition, Sebastian De Elcano, who sent a written report (in Spanish) to King Charles V upon entering to San Lucar in the mouth of the Guadalquivir River. Jakov de Baninssis, who originated from the island of Korčula, sent the translation of Elcano's letter of September, 1522 to Ragusa. Thus, in his letter of April 6 ${ }^{\text {th }}, 1523$ from Trento, he wrote: “...This ship, on her return brought circa 300000 ducats in gold, pearls, gems and spices. Another ship, being expected, carries as much in goods..." Jakov from the island of Korčula sent another letter with his own to Ragusan authorities, which letter was written by "Capitan de Pons" (Juan Ponce Leon), Master of "Trinidad", at the port on the island of Tidor, on December $21^{\text {st }}, 1521 .^{78}$

The participation of Ragusan fleet in military raids waged by Charles V, King of Spain, to Africa in the years 1535,1541 , and 1542 , and Portugal in 1580 was obvious. ${ }^{79}$ Ragusans participated (with their ships) in the Spanish "Invincible armada" in 1588. ${ }^{80}$ So the ship Santa Maria de Gracia y San Juan Bautista de Sicilia (Ship Martolosi) under the command of Luka, son of Ivan Kinković, owned by merchants Vice, son of Petar Jug, and Jaketa Martološić) was in fact a carrack (800 tons) with 100 mercenaries

\footnotetext{
69 Luetić 1971a: 93-97; Luetić 1960a: 355-359; Luetić 1976b: 459-463.

70 Luetić 1959a: 129-141; Luetić 1966b: 269-278; Luetić 1966a: 290-293; Luetić 1997: 118-128.

71 Luetić 1954: 75-79.

72 Luetić 1958: 213-218; Luetić 1969a: 109-115; Luetić 1977b: 167-178.

73 Luetić 1966c: 71-74; Luetić 1967: 130-132.

74 Luetić 1959c: 53-63; Luetić 1975: 90-98; Luetić 1984a: 90-92.

75 Luetić 1976a: 95-116; Luetić 1982a: 756-769.

76 Luetić 1964: 29

77 Luetić 1982b: 165-166.

78 Tadić 1931a: 239-240.

79 Šerović 1926: 250.

80 Novak V. 1953: 604-611; Kostić 1972: 196-235; Kostić 1977: 47-61; Luetić 1988c: 237-240; Luetić 1988a: 141-149; Luetić 1988b: 13-14.
} 
(Spaniards and some Sicilians). The ship pressed into service for the Levant squadron of the Spanish armada, near Sicily, was chartered out by the Ragusan owner for a sum of 1.000 scudos per day. By a combination of war and weather circumstances, the ship was wrecked near the island of Mull (Tobermory) by the west coast of Scotland and, according to some stories, she was transporting treasure - "30 000 in coins". At the depth of approximately $18 \mathrm{~m}$, she was rather damaged and the transport of larger amounts of money was jeopardized (in "chests with gold") by the ship which was, in this concrete case, assigned for battles. ${ }^{81}$ Vicko (Vicenzo) Martološić was mentioned in the quotation of the statement (Ferrol, June, 1590) on wreckage of the Ragusan ship Santa Maria de Grazia e San Giovanni Battista that had participated in "The Invincible Armada" in $1588 .{ }^{82}$ The ship was often called "La nave Martolossa". ${ }^{83}$ That ship (of a nao type, as called by Marolin de Juan) had not been originally built as a battleship, but for trade, and nevertheless she served in the Spanish Navy for several years, and was one of larger "Levantine" merchant ships called argosies (Ragusan) by the English, "undoubtedly, for a major part of the Levantine trade with England was carried out from Ragusa in the early $16^{\text {th }}$ century." 84

The unmistakable influence of Ragusan shipping in the Mediterranean and worldwide, and its "noticeability" and significance appeared in a synthetisized survey on shipbuilding achievements. ${ }^{85}$ It is interesting that Vice Martološić was an embodiment of foreign influence on the Spanish shipbuilding in the early forties of the $17^{\text {th }}$ century, so that the Spanish Crown appointed him to build the new ordenanzas. He arrived in Spain to serve the king with his naval squadron and was later upgraded to the position of Administrator to build the Atlantic fleet. He did not observe specifications given by the Crown, but he offered new details, for "a perfect ship building" which were the fruit of a longer study. He "revealed the truth that nobody had reached, thus far". $\mathrm{He}$ planned to tell the secret to the King of Spain in return for the citizenship for his two sons: the command of a galleon to the first one, and the ecclesiastical benefices for the other. He planned the salary and the title of a general for himself. "I do not think that it

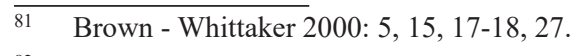

82 Kostić 1975: 550.

83 After one of the co-owners - Jaketa Vlahov Martološić (and Vice Petrov Jug). That ship under the command of Luka, son of Ivan Kinković, was called differently. Beside "La nave Martolossa", she was also called "Santa Maria de Grazia e San Giovanni Battista", in Spanish documents she was called "Santa Maria de Gracia (y San Juan Bautista)", and during "The Invincible Armada" "San Juan de Sicilia" while in the English sources she was known as "La Florencia", "La Florida", "The Tobermory Galleon", and some other names. Kostić 1975: 416. See also: Tadić 1932: 121122; Novak V. 1953: 606; Kostić 1972: 211, (211-225); Kostić 1977: 51-52, (52-56).

84 Hardie 1912: 43

85 Thus, in the work: Eyüp Özveren 2000: 15-86, on pp. 21-22 and 50, Ragusan shipbuilding is placed in the world's context. Author cites F. W. Carter, J. Tadić and R. Roman, while works by (V. Bačić, V. Foretić, V. Ivančević, J. Lučić, J. Luetić, I. Mitić, S. Vekarić and others) failed to take their place there. However, this most recent excellent work on shipbuilding nevertheless mentions Ragusan shipbuilding, while others, most frequently, wouldn't even do that. 
is too much to ask for", he added, for these benefits are only temporary in comparison with the gift "of competence which is everlasting". King Philip IV, ${ }^{86}$ devoted to orgies, theatre and love affairs as a "prisoner of ceremony", gave in to his offer to build a perfect ship in full trust. It was by 1643, that Martološić was given the honour of a general and was characterized as the author of "currently implemented ordenanzas". Tomo, his son who worked with his father, took the specifications to Italy, and was appointed in Naples to carry out the function of a manager while building six galleons for the Atlantic fleet. The new prescribed ways of building were never published and the only record was the Martološić's specification of laying a higher keel in relation to the largest breadth of a ship in the ratio of 1:3. This had an impact upon the construction of the new Admiral ship of the fleet in 1649, and in comparison with her predecessor of 1628 , she demonstrated an enlargement by $5 \%$, in relation to the keel, and the largest breadth of a ship. ${ }^{87}$ Girolamo (Jerome) Mažibradi(c) set off into the world "looking for a better living", because of his numerous family origins. His brother Nikola Mažibradić wrote from Madrid to Ragusa in 1634 that he had completed his six years' service with his galleons, but was invited to stay on for another 6 years. Jeronim Mažibradić (Don Geronimo Marques de Masibradi) and Kristo Martološić (Don Christoval Martolossi) were mentioned as commanders (generals) of naval squadrons. ${ }^{88}$ Nikola Mažibradić, the Ragusan ship-owner, who had also significantly contributed to the Spanish naval force, bought the ship "San Sebastián", sold as "inappropriate for warfare" and destined to serve a new master in the so called "Italian squadron" in the Spanish Navy. ${ }^{89} \mathrm{He}$ was, together with the admiral don Francisco de Vallecilla, loyal to Antonio de Oquendo in

86 See more about this sovereign: John Huxtable Elliott, Philip IV of Spain, Prisoner of Ceremony, The Courts of Europe, (ed. A. G. Dickens), London, 1977; Idem, Power and Propaganda in the Spain of Philip IV, u book: Rites of Power. Symbolism, Ritual and Politics Since the Middle Ages, (ed. Sean Wilentz), University of Pennsylvania Press, Philadelphia, 1985, pp. 145-173; J. P. A. Bazy, État militaire de la Monarchie Espagnole sous le régne de Philippe IV, Poitiers, 1864; M. Devéze, L'Espagne de Philippe IV, 2. Vol., Paris, 1970; Martin Hume, The Court of Philip IV, London, 1928. There is an interesting possibility that, Vice(ntije) Martolosić was a Viceroy, i.e. Spanish Royal Regent in Mexico, yet only during the reign of Philip II. See also: Foretić 1960: 149.

87 Goodman 1997: 117-118. As a fruit of a long scientific research in national and local archives of Spain, author brings on page 118, in notes 43-47 the original signature from Archivo General in Simancas in connection with Vice Martolosić. See also: Bašić 2003: 85-86; Bašić 2004: 192-193. While most of galleons of Elisabeth I were built in length-to-breadth ratio of 2.5:1 and during the reign of Charles I in 3:1 ratio, new ships launched from 1646-1647 had a 3.5:1 ratio. See: Parker 2001:100.

88 Gelcich 1889: 100, 107. So it is said for Jerolim Mažibradić (Girolamo Mašibradi) that he was paid in annual salary of 2.400 escudos in the rank of the highest commanding order of the Spanish Navy (captain-general), and his brother Nikola was a marquis and the knight of St James of Compostela (Santiago de Compostela). Jerolim Mažibradić was captured during a surprise attack (a fleet of 22 pirate galleys from Rhodes) and was sent as a slave to Scio, but was soon paid ransom for him. See also: Villari 1904: 312-313 (data according to Gelcich).

89 Phillips 1992: 189. In this book, the author brings details about 6 galleons built for Spanish crown from 1625-1628 from archival sources in Madrid, Seville and Simancas. 
setting off with a fleet of 26 ships and almost 5.000 people to Brasil at the beginning of May, $1631 .{ }^{90}$ And so Medina de las Torres, the Neapolitan Viceroy, in his letter to Philip IV, of March $11^{\text {th }}, 1639$ particularly mentions two ships from Ragusa (of 1.200 tons and 1.000 tons) and 4 Venetian ships (with Venetians signed on) which belonged to the Atlantic fleet ("la armada del mar Oceano"). ${ }^{91}$ During the conflict between the Dutch, commanded by Maarten Tromp, and the Spaniards, under Antonio de Oquenda, off the port of Dunkerque where Oquendo was, Nikola Mažibradić's galleon is also mentioned when in the night of October $21^{\text {st }} / 22^{\text {nd }}, 1639$ along with the Flemish squadron freed the Commanding Admiral (capitano) ship "Nuestra Señora de la Concepción y Santiago" from the enemy encirclement. It was later that Tromp sadly admitted that the ship was invincible with De Oquendo in command. A storm drove the Dutch ships away thus ending the battle the following day ( $22^{\text {nd }}$ October). De Oquendo's commanding ship (capitana), was kept afloat by five pumps, and was bound for Mardick accompanied by the Mažibradić's galleon and seven of them from Dunkerque. She arrived in Mardick on October $23^{\text {rd }}$, being the largest ship that had ever called at that port, under the secure pilotage by Miguel de Horna (Miguel de Orna). The list of damages stated that the ship had suffered 1700 blows. $^{92}$ De Oquendo left the port on February $15^{\text {th }}$, 1640 , choosing the risk of storm rather than a new confrontation with Tromp, and so returned to Spain. According to some sources, Spain lost 6000 vassals (mostly Castilians), 43 ships, 600 bronze guns and a considerable number of senior and junior officers, while Portugal lost the ship "Santa Teresa" and 900 men. ${ }^{93}$ The Dutch captured nine Spanish galleons, but six of them sank before reaching port. The chief printer of the city of Seville, Juan Gómez de Blas, printed "the true connection of the great victory of Don Antonio de Oquendo over the Dutch ships in the English Channel" in the form of the contemporary Spanish relaciones (a kind of irregular and informal newspapers that dealt with local and foreign news in an encouraging and comforting style) ${ }^{94}$

Relatively good and close relations between the Ragusan Republic and Spain could be discerned on the occasion of St Blaise Feast (on Candlemas) when the Admiral of the Ragusan navy hoists the flag on Roland's column with a eulogy invocating some saints by their names - mainly those of Rome, then Zadar, Kotor, Trogir, Split, Naples, Lipari, Bari, Monte, Ancona, Genoa, Milan, and also St Vincent of Spain. ${ }^{95}$ The Consul of Aragon was mentioned as early as in 1422, while Philip IV, the Spanish King

\footnotetext{
90 Phillips 1992: 189-190.

91 Coniglio 1990: 1439-1441.

92 Phillips 1992: 218.

93 Boxer 1930: 66, note 1. Compare to: Stradling 1992, (2003): 88-89, 106-108, 114-115.

94 Elliott 1986: 550-551. It is an integral book about Gaspar de Guzmán Olivares.

95 Macan To 1936. In the Dominican Monastery (Priory) in Dubrovnik, there is a picture of "Martyrdom of St. Vincent", whose author is probably Franjo Matijin (?). See more: Krasić 2002: 65-66; Krasić 1998: 242-243. See more about the author, not necessarily of that painting: Prijatelj 1995: 233-234.
} 
appointed Petar Ohmučević as the Spanish agent and consul in Ragusa. He held the office till his death (1631), when his son Stjepan took over (till 1637), followed by his brother Nikola Ohmučević (till 1666) and Petar, son of Stjepan Ohmučević (perished in the earthquake in 1667). ${ }^{96}$

Fynes Moryson, writing about Ragusa in 1595, said: "It conducts a lively overseas trade, and owns large ships that were often hired by the Spanish king as an addition to his navy". William Lithgow in 1609, George Sandys in 1610, Paul Rycaut in 1668, and others also mentioned a large number of Ragusan ships. ${ }^{97}$ However, the Ragusan political wisdom and diplomatic prudence in their relations with all countries did not acknowledge any boundaries, when the preservation of their own was at stake. Merchants from Barcelona and Valencia had been present in Ragusa since 1341 and together with Ragusan tradesmen they set up a trade society (societas) for the purpose of trading with Hungary. The Spanish were selling salt to Ragusans in Ragusa and at the same time were buying falcons trained for hunting, bartered cloth for lead, silver, sumach wood, hide (cowhide, goatskin, and rabbitskin), and else.$^{98}$ The Ragusan Republic considered the present of twelve hunting birds (falcons or hawks) for the Spanish King and the Viceroy in Naples, as a gift, and not an obligation. The Neapolitan "Governor of the Arms" in his nominal function, from 1678 to the fall of the Republic, was treated likewise. ${ }^{99}$ It is reported that the Ragusan authorities sent twelve falcons to the Spanish Commisioner Ossumi in Naples (letter of October $1^{\text {st }}, 1658$ ), to be delivered by Petar Ivelja Ohmučević. ${ }^{100}$ Other Ragusans sailed to "the West Indies". ${ }^{101}$ Many endeavours and achievements in the art of shipbuilding raise the East Adriatic coast above the West one, since it had most frequently been a successful way in which ships and men reached different parts of the world. ${ }^{102}$ Nikola Mirković said that "West

\footnotetext{
$96 \quad$ Mitić 1965: 121.

97 Levental 1989: 57, 69, 74, 146. See more in another work: Bošnjak 1952: 451-457.

98 Lučić 1991c: 491, and thereby the quoted literature.

99 Mitić 2004: 103-104. See also: Mitić 1969: 485-505; Mitić 1970: 277-296; Mitić 1972: 120-121; Mitić 1973b: 192-194; Mitić 1978: 113-135; Mitić 1985b: 57-58; Mitić 1985c: 261-264; Mitić 1986: 101-132.
}

100 Kojaković 1930: 4. Yet, for example, in 1407 hunting with falcons was forbidden in the urban area of Dubrovnik (Ragusa). See: Rešetar 1922: 2.

101 And so Florio from Trsteno, who owned the ship "Santa Lucia" in Indiana, and who built his ships "Santa Croce" and "San Bonaventura" in Gruž. It is considered that he brought a crucifix to St Vitus church in Trsteno, as a token to a dream he had dreamt in the Atlantic (Savior crucified). He had invested into principals in Naples, but his deposits were lost when the city was conquered by the The House of Savoy. See more: Ivanović 1931b: 4; Ivanović 1931a: 2.

102 And so, Leonardo Bressan was the main person in charge of shipbuilders of the Venetian Arsenal (from 1498 till 1540). According to Marino Sanuto's words, his barza of $1.200 \mathrm{t}$ (450 men, over 400 guns) was: "a palace (...) one of the most beautiful achievements which could be seen at sea for many years". Matteo Bressan ( $\uparrow 1528)$, possibly Leonardo’s younger brother (?), was in the period from 1503 up to 1525 and later on till his death, one of the best and the most required builders of galleys of the time. So, he took on an assignment to build 12 out of 21 galleys in 1522, while other shipbuilders completed 1-2. It was the renowned family of shipbuilders and 
Indian fleets" (of Ragusa), "particularly those of Ivelja, (D)olistic, Martološić and Mažibradić, created history in the Caribbean, in Brazil, England and Flanders", and stated that 1/3 of the Spanish Navy in the oceans (1588-1640) consisted of Ragusan "Squadre dell'Indie" and "Squadre del Mar Oceano", which were built, managed by Ragusans and under their command. ${ }^{103}$

Ragusan Miho Pracat (Michael Prazattus, Michele Praz(z)at(t)o, Michele Prazzati, Michaelis Prazzati, Michieglie Praz(z)at(t)i, Michele di Paol Prazatouich, Prazzati) (around 1522-1607) of the island of Lopud is an example of the human persistence. There is a well known story of a lizard he watched as it was climbing a wall: the lizard fell off the wall twice but succeeded in its third attempt; similarly, after two unsuccessful voyages, Miho Pracat became rich in his third attempt. Another legend has it that, during a great crisis in Spain, Miho Pracat brought a lot of grain and King Charles V (while he was shaving himself) received him and invited him to choose a reward for his good deed. Miho replied: "I am rich enough to seek riches; I do not wish honours, since I am the ruler of my ships; titles I do not seek, for I am the citizen of the Ragusan Republic. But, may Your Majesty be so kind as to let me have this cape to keep as a keepsake in honour of Your Mercy." This cape is nowadays still kept in the rectory on the island of Lopud. He left a part of his fortune in his last will to be used for buying off slaves. His bust was erected (in the Rector's Palace, Ragusa in 1638), the sole monument ever to be erected in honour of a commoner by the aristocratic Ragusan Government. ${ }^{104}$ A legend from Orašac and a similar one from Župa dubrovačka near Dubrovnik, tell a story of a lunch when Miho Pracat noticed a chicken wish-bone and, pondering upon the position of the bone, came upon the idea of building a new ship (keel) after that model, which brought him bags of money. ${ }^{105}$ Miho Pracat's estate (houses, not money) exists to this day. "Opera Pia", the Charity Foundation, "still in 1930 pays every year, according to his last will, a revenue from his principal" ("one half to the poor of Ragusa, and the

Francesco Bressan also originated from it, being significant in the sixties of the $16^{\text {th }} \mathrm{c}$. See: Lane 1992: 60, 62-63, 212. It is considered that Matteo Bressan built "the first" galleon for Venice in the period from 1526 to 1530 . Prior to the vessel's unrigging/dismantling (1547) shipbuilders had taken her measures. See: Lane 1992: 51; Kirsch 1990: 3-4, 108. A book that was recently published was written by Ray Martin 2001: 256 in which a great deal of merits in shipbuilding are attributed to Venetians. The French (during Colbert's domination) imported foreigners for building ships, and Biagio Pangallo, a Neapolitan (with the French known as Maitre Blaise) in the $17^{\text {th }} \mathrm{c}$. He made a refined construction and "curtailed" (lowering) her hull a little forwards and alongside curving of her (decks) a little backwards, he obtained somewhat faster speed, and "taught the French to be the best constructors of warships in the world". See: Jenkins 1973: 40. Mirkovich 1943: 175, 186. Unfortunately, author's finding on insufficient research into the Ragusan maritime endevaours in the West Indies and in the Atlantic, in its major part is valid to this day.

104 Tadić 1933a: 5, 14, 34-35, 50-55; Lisičar 1932: 79-85; Pavlić 1907: 36, (73-80), (118-125), (226-233); Vučetić 1907: 700-707, 750-753, 797-800, 841-845, 894-898, 1036-1040; Cvjetković 1927: 63-66.

105 Macan To 1983: 157. On pages 159-160, the author publishes an interesting contribution under the subtitle "Old measurements in rural memory". Macan To 2001a: 358. 
other to the poor of Luka Šipanska and Koločep in equal shares"). ${ }^{106}$ A fragment of the sepulchral stone slab with the inscription "Prazatoviz is built into the cloister wall surrounding its central garden in the Franciscan monastery in Dubrovnik." ${ }^{107}$ Quite often, women played the role of masters of the house as widows or abandoned wives without any news of their husbands or their heirs (sons) who were often taken prisoners. Miho Pracat, as a dignitary of the island of Lopud, acted as an executor of female and other last wills in many cases on Lopud. ${ }^{108}$

Soldiers from papal galleys looted the island of Lopud in 1538. Ragusan envoy Dživo Sorgo complained to the Pope in Rome in the summer of 1538 that the subjects of Ragusa "were looted in a way that neither the Turks nor the Moors would have done...". Namely, 12 papal galleons anchored on July $2^{\text {nd }}, 1538$ off Lopud and by a surprise attack (initially bringing well-intended supplies) looted the settlement. No wonder that the providore of the papal galleys was Giovanni Gritti, a Venetian. Even the rector of the island was captured (some time later released) with 6-7 Ragusan nobles and children (12-14 years of age) and old men taken away onto galleys, while the soldiers broke into churches in a purpose to obtain information about hidden treasures of the islanders. ${ }^{109}$ Serafin Razzi stated that culprits were subjected to severe punishment (the thief who had stolen the crown from the main church of The Lady of Šnj was hanged), while the stolen goods were allegedly returned to their owners. The commander of the papal fleet, patriarch Grimani of Aquilea was allegedly off Cavtat port (according to Serafino Razzi) or Molunat (according to Nikola Ranjina). ${ }^{110}$

It was wise to possess more shares (carats) in several ships, rather than to possess complete shares in a single ship (because of the risk from pirates, adverse weather conditions, and the like), what was already recommended by Benedikt Kotruljević. Thus, Vice Stjepović-Skočibuha (1534-1588) from Suđurađ on the island of Šipan held shares (carats) in 17 sailing vessels di lungo corso, and ended up his maritime career as Captain of the ship "S. Caterina", and retired "...due to his weakness caused by fear and horror suffered from witnessing his own brother's and many sailors' blood spilt on board...". He gave copious means to redeem Christians from slavery (North Africa). ${ }^{111}$

According to some quotations, Vice Bune (Vincentio Bune(o), 1559-1612), a Ragusan seafarer and a diplomat was even the Viceroy of Mexico, ${ }^{112}$ although not mentioned in some of the lists containing names of the viceroys (high officials in The

\footnotetext{
106 Lisičar 1930: 4.

107 Lisičar 1933: 1.

108 Stojan 2007: 195, 199-200.

109 Tadić 1933: 29-30.

110 Lisičar 1933: 1.

111 Luetić 1984b: 97-98; Tadić 1928d: 22; Tadić 1948: 207, 233.

112 Appendini 1803: 201; Luetić 1952b: 257, 265-266; Luetić 1952a: 4; Luetić 1959b: 285-286.
} 
Indies) (despite a "blank space" from April 19 $9^{\text {th }}, 1583$ till September $\left.25^{\text {th }}, 1584\right) .{ }^{113}$

Alongside Florence and Venice, Ragusa was on top of the social scale by their achievements in the Renaissance (social organisation and management system), considerably greater than in some other parts of the world. Thus, the Ragusan Republic was most likely placed among the most developed countries of the $15^{\text {th }}$ and the $16^{\text {th }}$ century, probably by four times more developed than the areas of northern parts of South Eastern Europe. ${ }^{114}$ During the $16^{\text {th }}$ century, there were $200-250$ Ragusan captains on record. In the period between 1539 -1544, theRagusan Republic had 132 ships of deadweight totalling 15200 carri and 3000 seafarers, while in the period 1570-1585 there were as many as 182 ships of total deadweight of 36.500 carri and 5500 seafarers. ${ }^{115}$ In the mid 1599, Ragusa had 52 sailing vessels (over 100 carri) fully rigged for deep-sea navigation (45 navas, 6 galleons and one urka; totalling a deadweight of 20.720 carri). Regarding smaller ships (10-80 carri), there were possibly more than 60 of them and so the total deadweight of the Ragusan fleet, according to some authors, was 23.720 carri in $1599 .{ }^{116}$ During the $16^{\text {th }}$ century, there were $3000-5000$ crew members employed on board Ragusan ships. Having the possibility to sell smaller quantity of goods without paying freight for a higher profit from their salaries, the ship crew could earn approximately 100.000 ducats. If we exempt the ship crew, revenues generated from shipping amounted to 200.000 ducats during the $16^{\text {th }}$ century. Some Ragusan vessels sailed for almost 40 years, while in other countries the average duration was some twenty years. Old Ragusans obtained wood for ship masts (made of spruce-wood up to $30 \mathrm{~m}$ long) from Senj and Rijeka. Ships were being built for at least one year, and sometimes even 2-3 years. Small ships (several deadweight tons) cost 50 ducats in the $15^{\text {th }}$ century, while ships of 30-80 tons cost several hundreds ducats. The Ragusan Republic possessed 170-200 ships in the $16^{\text {th }}$ century, the greater part of them of more than 100 deadweight tons, while they also possessed ships of 400-500 and 600 tons. A ship carried over 1300 tons of wheat in the second half of the $16^{\text {th }}$ century, and another built in Gruž in 1568, approximately 1500 tons. This largest Ragusan vessel of the time was valued at 20.080 ducats and had a crew of 140 members. Total deadweight of Ragusan merchant marine amounted to 20.000 tons (valued at 200.000 ducats) in the first half of the $16^{\text {th }}$ century, while it reached 50.000 tons in the second half of the $16^{\text {th }}$ century (ship's value was $600.000-700.000$ ducats). ${ }^{117}$ According to

\footnotetext{
113 Polić-Bobić 1986: 224-225.

114 Vinski 1975: 553-554.

115 Tadić 1952a: $175,179-180$.

116 Vekarić S. 1954: 427-430. Vekarić S. - Vekarić N. 1987: 12, note 6; Vekarić S. 1997: 267, note 6. Otherwise, 1 carro $(\mathrm{kar}, \mathrm{kola})=0,711$ register tons or 2.000 1. is used in the Kingdom of Naples. See: Vidović 1984: 205; Luetić 1969: 16-17. Ragusan libra or litre ('fat' ad pondus grossum) = 358,46 g. See: Liber Statutorum 1989: 9; Statut grada Dubrovnika 2000: 671 - libra quoted herewith $=328$ grams (it doesn't say, but it is obviously 'thin'- ad pondus subtile - for gold, silver and pearls).

117 Tadić 1952b: 57.
} 
the old common law in Ragusa, the ship-owners and captains took children on board (“mali"-ship's boys) by having previously concluded an agreement either with them or with their parents/guardians before a Notary Public, obliging boys in the long run to serve their captain for 2-4 years and to be paid by him in the end the salary agreed upon. Captain's statement referred to their feeding and clothing during the service (in health or illness). There were 10 boys on board ships of 500 deadweight tons, and up to 20 on larger ones. By decision of Ragusan Senate (1557), "mali-ship's boys" would get financial aid (in fact a loan). The Ragusan ships hired (3 of them) in advance would take 10 sailor boys on a voyage from Alexandria to Syria, while Ragusan authorities would lend them 200 ducats each to invest into various colonial goods in the Levant. On their return, money would be given back to the Ragusan authorities, and each child had to previously acquire good creditors. Thus, children (on long voyages) developed their maritime and trading experience, and at the same time accumulated initial capital for trading. ${ }^{118}$

More than 16.000 tons (tonnellate) of silver was brought to Spain from their colonies during the $16^{\text {th }}$ century, the additional 26.000 tons in the $17^{\text {th }} \mathrm{c}$., and another 39.000 tons in the $18^{\text {th }}$ century. The system of two annual convoys depended on the winds prevailing in the Caribbean, north and south, so that ships from New Spain (Vera Cruz, called flotas ) sailed out in March or April, while those from Tierra Firma (nowadays Columbia, from Portobello on the Panama isthmus or Cartagena), collectively called galeones, departed in August and September. At very best, those from Spain would leave in March and September. Don Luís Alfonso de Flores was the commander of the fleet exceeding 40 ships that set out from Seville to New Spain in 1594, while Andrés Canel from Seville transported blankets, various crockery, fabrics, clothing and foodstuffs such as oil, olives and sugar by the same fleet. The New Spain armada (fleet) of (capitán general) don Alvaro Flores de Quinones arrived in Seville on September $13^{\text {th }}, 1583$ and another from Tierra Firma under the high command of don Diego Maldonado, transporting silver ingots and coins shipped from Corona, on the total number of 70 ships. Madrid was informed by Mexican authorities in 1602 that transport of silver from Acapulco to Manila cost 5 million reais (approx 143 tons) per year. Portuguese ships transported annually between 6 and 30 tons of silver ${ }^{119}$ from Macao during the $15^{\text {th }}$ and the $16^{\text {th }}$ century .

It is usually said for the second half of the $16^{\text {th }}$ century or for the entire $16^{\text {th }}$ century that it was " the Golden Age" of Ragusa, but it was the silver age, for Ragusans were modest and according to them and without them the golden age would not have happened, as attributed to the fact that they did not mint gold coins. Earnings by trading silver, beside its cultural and artistic role, were, in fact, the true "glitter". The Ragusan mint did not issue gold coins, despite the provision passed by the Ragusan Senate in

\footnotetext{
118 Tadić 1936a: 68-69.

119 Cipolla 1996: 7, 24-25, 28-29, 54, 66.
} 
1517 (later on postponed and never realized) about the beginning of minting golden coins (ducats) similar to those of the Venetian Republic. According to some indicators, European trade with the East "devoured" about 80 tons of silver every year around 1600 . The Ragusan Republic paid an annual tribute of 12.500 ducats to the Ottoman Empire, which was in its mission of a trading character (initially as a voluntary contribution for its protection, privileges or reduction in customs duties). ${ }^{120}$

Among other things, Ragusans were founders of modern consulates and the advanced regulations from the $14^{\text {th }}$ and $15^{\text {th }}$ centuries speak in favour of Ragusa that was, at a certain point of time, even ahead of Venice. The Byzantine emperor gave permission to Ragusans in 1451 to have their consul in Constantinople and to erect a house for him, while the Council in Basel in 1433 allowed them trading with "infidels" and installing their consul in Turkey. ${ }^{121}$ Ferdinand, the Spanish King issued a special permit for free trade to Ragusans in 1479 , so they were exempted from port fees in 1485. Ragusa had 22 consulates in the Mediterranean at the end of the $15^{\text {th }}$ century. The Ragusan Republic had 50 consulates (44 in the West, and 6 in the East Mediterranean). There were 9 additional consulates in the West Mediterranean during the second half of the $16^{\text {th }}$ century. Due to their trade and the shipping constellation, there were in general 30 consulates in the beginning of the $17^{\text {th }}$ century, 2 in the Levant - in the Albanian port of Valona and on the island of Zante, and others along the Adriatic Sea or in the West Mediterranean. During the Candian war in 1645 and until the decision of the Ragusan authorities (1657) to concentrate their trade on the Adriatic, 14 consulates were mentioned. There were fewer consulates of European states in the West than in the East (Levant) from the $15^{\text {th }}$ up to mid $17^{\text {th }}$ centuries. After the disastrous earthquake in 1667 (in the second half of the $17^{\text {th }}$ century), Ragusa had 17 consulates in the Mediterranean (12 in the West, 5 in the Levant) until its forces were consolidated. Ragusan authorities implemented cost-cutting measures to increase state revenues by the Ordinance on Trade Improvement (1668) and the Customs Duty Ordinance for foreign Levantine merchants in Ragusa (1670) and also by Special Ordinance of 1670. After the disastrous earthquake, customs duty was reduced for English (cloth) and foreign merchandise. The Ragusan Senate banned sailing outside the Adriatic to all commanders of Ragusan ships without a special permit in the middle of 1677, while the Decision on ban of issuing patents (seamen's books) to Ragusan subjects - commanders of foreign vessels ${ }^{122}$ was passed in 1690 .

The Ragusan diplomacy ensured a strong economic development permeated with freedom prescribed by the Senate - the appointer of envoys and consuls, and with the art of persuasion the representatives of Ragusa gained over the foreigners. Freedom of

\footnotetext{
$\overline{120}$ Pierucci 2001: 30, 37, 60. On p. 60 there is some mentioning of the amount of 12.000 ducats of the annual tribute, but it was in fact from 1478 i.e. 1481 that the sum was consolidated at 12.500 ducats. See: Stulli 1989: 46; Stulli 2001: 13.

121 Krizman 1957: 24-25, 33.

122 Mitić 1973a: 37, 40, 50, 54; Mitić 2004: 111, 114-116.
} 
grain exports meant also good relations with their neighbouring countries. Ragusans usually obtained grain from South Italy, Sicily, the Papal States, Albania, Eastern Greece, Thrace and present Bulgaria (rarely from Egypt and South France). Sometimes, Ragusan authorities had no choice and therefore they ordered grain transport expressly and drew lots for the ship that would transport a defined quantity of grain to Ragusa in the following year, and the disobedient/trespassers were levied fines (in more serious cases the authorities would order demolition of a house of the person involved). Venetians would block the port of Ragusa, like during the whole year of 1538, and stop ships (loaded with grain) arriving from the Levant. ${ }^{123}$

On various occasions, Ragusan envoys (landed aristocracy, nobility) left Ragusa, thus Saro Gučetić sailed out for Cadiz in February (as was the Ragusan custom due to their trip to England) and Seville, and returned in July the same year of 1522 . He sent a written report on July $16^{\text {th }}, 1529$ against a Ragusan who had smuggled 20 bales of various fabrics and a chest of soap from Ancona and Neretva to Mostar, although warned to take the said goods to Ragusa. A Ragusan vessel on her voyage to the Mediterranean was attacked by pirates 1530/1531 off West France (Brittany), when the owners of the English cargo from Ragusa sent Saro Gučetić with the task of salvaging the ship and fabrics. Dyed goatskins (88) and ermin furs (708) were delivered to Gučetić by certain Frano Boljoević, to take them to Lyon, to sell and buy various fine fabrics. Ermin furs were from Constantinople, and 100 ermine furs were valued at 15 ducats. ${ }^{124}$

Serafin (Saro) Gučetić (Gozze) made a contract with a captain from Rijeka dubrovačka on January $8^{\text {th }}, 1532$, to take him and the merchandise to Ferrara for a price of 25 ducats, provided he did not accept anyone else or any other cargo on board. Actually, through mediation by Gučetić, a three year trade peace was concluded between the French King and sultan Suleyman in May, 1534 - in other words, an unofficial political agreement between Turkey and France against Spain. Serafin Gučetić sailed to the Levant and ended up in slavery 1537/1538, so that his wife's trustees were granted a loan of 200 ducats by Ragusan authorities on October $4^{\text {th }}, 1537$ for his ransom on October $4^{\text {th }}, 1537 . .{ }^{125}$ Saro Gučetić died somewhere abroad in $1547 .{ }^{126}$

Filip Trivulzio, the archbishop of Ragusa originating from a Milan family, arrived in Ragusa in 1521 or 1522, after having been caught by pirates, according to some sources, and paid ransom by Ragusans. A great admirer of the French and their spy, he was an adversary of Spaniards (as he had allegedly seen them ransacking Rome), who was exchanging correspondence with the French king sending him information and was receiving the French who were travelling through Ragusa. Trivulzio made an almost fatal harm to Ragusa, since at the beginning of the war against Turks Ragusans

\footnotetext{
123 Tadić 1928b: 43-44, 46.

124 Tadić 1937b: 453-454.

125 Tadić 1938a: 18, 23, 38.

126 Tadić 1938c: 61.
} 
were French allies and enemies of Spaniards and their allies. A Venetian ship reached Slano near Ragusa in June 1537 and, due to bad weather, she could not continue her voyage to Kotor. Ragusan Petar Pucić informed the archbishop about a person who was carrying letters from the Venetian government to the rector of Kotor from the ship by land, and those letters were seized in Konavle near Ragusa. Trivulzio dispatched coded letters to the French envoy in Constantinople and it seemed that the report (for the rector of Kotor) was on the forthcoming battles with Turks. Venetians attributed to Ragusans this "breach of the international law" and aided Turkey, so they planned conquering Ragusa, which had on several previous occasions and subsequently resisted foreign aspirations. Upon defeat of the Christian army by sultan Suleyman near Pécs in 1543, the archbishop Trivulzio congratulated the sultan, who sent him 10.000 silver ducats. When the archbishop died in 1544 (whether poisoned or not), Ragusan authorities could breathe a sigh of relief. ${ }^{127}$

Frano, son of Frano Gundulić, the Ragusan envoy to Rome, in his report (1573) to Pope Gregory XIII mentioned "33 large Ragusan ships (navas) which were escorted at the rear by Christian Navy, but because of dead calm could not make it to the battlefield of the Battle of Lepanto on time" (1571). These, probably somewhat fabricated data, were reported to the Pope who was not in seat during that battle. Gundulić had in that sense acted for the wellbeing of his government and the Ragusan Republic. ${ }^{128}$

The conflict between France and Dubrovnik emerged in the seventies of the $16^{\text {th }}$ century due to the competence of the French consul in Alexandria, since France had been previously acknowledged as the main representative of Christians in the Ottoman Empire and thus, for the purpose of trade across Turkish lands, all Christians (except for Venetians) used the French flag. ${ }^{129}$

A unit of Venetian Navy included some Uskoks among its crew, and so they came to Slano near Dubrovnik after Uskoks had lost their stronghold of Klis in 1537. Uskoks disembarked on the Ragusan shore under the cover of night, carried on to Herzegovina looting some villages, but the locals retaliated (and recovered their property) on the Ragusan territory. Uskoks then looted a Ragusan village in the vicinity and killed a nobleman (the canon of the Ragusan cathedral). Venetian ships picked them up near Slano. The Turkish caravan was to leave Ragusa in the night of November $7^{\text {th }}, 1537$, so that the Uskoks from the Venetian galley anchored between Ragusa and the island of Lokrum the previous night futilly disembarked and during the day remained hidden near the city gate (former hotel "Odak", nowadays "Excelsior"). Then they attacked by night, captured their goods and a man as the caravan went up the slopes of mount Srd on its way to Turkey, and went back to the galley. Ragusan authorities sent their delegations to Venice, complaining and asking them to stop giving protection to

\footnotetext{
$127 \quad$ Tadić 1925: 14.

128 [Tadić] 1929a: 76-77. See literature on the Battle of Lepanto in paper by: Bašić 2007: 143-156.

129 Tadić 1938b: 17.
} 
Uskoks, "the ones who jumped in" ("the ones who ambushed"), while at the same time persuading Turks in Herzegovina and Constantinople by "evidence and gifts" and also that they (Ragusans) "do not permit Uskoks free movement on their territory". Uskoks broke through the Ragusan Dubrovačko primorje to Popovo polje again in 1539, and carried their booty onboard their ships, while Venetians gave them permission to set up their outposts on the eastern side of the island of Hvar, on Korčula, and in the vicinity of Split. The Uskoks looted the village of Janjina on the Pelješac peninsula in 1540 and, upon the settlement between the Venetian Republic and the Turkish Empire, Uskoks withdrew to Senj. Following the war between Venice and Turks in 1570, Uskoks operated across southern parts of Herzegovina and the Ragusan territory from their base on the eastern side of the island of Hvar. Danger from Uskoks threatened the western, most exposed and relatively unprotected, part of the Pelješac peninsula. At the beginning of February 1571, Uskoks broke through Vratnik, came ashore near Slano and proceeded to Popovo polje and during the night ransacked Herzegovinian villages again. Some Ragusan ships were attacked by 6 uskok boats in the vicinity of Vratnik, killing two Ragusans. They broke into Dubrovacko primorje where they looted houses, and continued to Herzegovina. Because of heavy attacks in June and July 1571, Ragusans fortified Ston, and sent ammunition to the island of Lastovo. Ragusans then launched all of their warships that sailed around Ragusan territorial waters, at the same time seeking protection from the Pope and the Venetian Republic. Uskoks intruded as far as the port of Gruž and attacked Rijeka dubrovačka, where they killed several soldiers in 1571. They also plundered Ragusan ships that returned from the Italian peninsula (1577) and attacked villages in Dubrovačko primorje. Mljet and Slano were looted in February 1588, when a lot of peasants were killed and the Venetian rector of Mljet was taken prisoner. Over the years after 1594, Uskoks frequently aggravated unprotected villages in the vicinity of Ragusa and the walled cities of Ragusa and Ston. Apart from Uskoks, some inhabitants of Hvar, Makarsko primorje and others attacked Ragusans and consequently ended up on the gallows. Uskoks attacked Pelješac again in March 1596, plundered some villages and set out to Mljet, but they were defeated by the rector of Pelješac. ${ }^{130}$

Uskoks circulated near the Vratnik channel in February 1571, the year of the Battle of Lepanto, killing several men, and broke into Herzegovina through Slano. Uskoks captured two Ragusan ships some time later and carried away some smaller guns. These Uskoks were captured by the Turks from the Neretva valley and these Turks were in their turn captured by Venetians who then accused Ragusans (on the account of the guns) for supplying Turks with ammunition. Venetians used to hang Uskoks on the masts of their galley. ${ }^{131}$ The Ragusan Government informed their envoys in Constantinople on July $20^{\text {th }}, 1571$ that they "had killed more than a hundred Uskoks, stressing

\footnotetext{
130 Tadić 1928c: 269-271.

131 Tadić 1931b: 8.
} 
that there was their notorious leader Juraj Daničić among them, and had wounded almost as many". Following the rumours on the courts across Europe, Ragusans had, after investigation on that delicate issue which started on April $14^{\text {th }}, 1572$, compiled a report including statements from neutral parties (official representative of the French king together with the vice consul of the Venetian Republic). In the introduction to the report, the Ragusan Government also tries to dissuade other rulers from the accusations "Daničić from Senj was called by betrayal from the open sea to the shore and they had him executed ". An eyewitness stated that he had seen Juraj Daničić blind folded (for he did not perish during the conflict). The Ragusan envoy (serving in Rome at the time) mentioned Daničić as "the one you had strangled". ${ }^{132}$

Christian inhabitants of the frontier-land considered Turks as a measure of evil ("worse than a Turk"). Men and women in Dalmatia insulted their enemies by comparing them through illegal relations with the Turks (ex. puttana dei turchi; "your mother is a whore and she is wooing Turks in Ragusa") and slanderers were taken to court. Sudden assaults on marsiglianas or brigantines could be undertaken "in a labyrinth of shallow channels leading towards the mouth of river Neretva", causing damage to the transport of Turkish merchandise for Ragusa and Ancona and galleys anchored or damaged in storms while sailing from the Albanian coast or from Ragusa to Venice were vulnerable. The death of Uskok Juraj Daničić was allegedly attributed to Ragusans "when he came to negotiate after the Ragusan commander had guaranteed him safety", even though the Ragusans had dispatched statements by foreign eyewitnesses for the sake of keeping their public reputation. The signers were the representatives of France and Venice in Ragusa. Ferocious pressures and attacks by Uskoks that followed soon on Ragusans were finalized after several years by the intervention of the Pope. The Great Council was forced by the bloody conflict with the Uskok harambašas - the brigand captains in (1596): "they look upon us the same way as upon Turks". However, "Uskoks acted according to their assurance that the ideal of antemurale Christianitatis is common to all Christians, and that the infidels were their common enemies". Uskoks complained to the Ragusan Consilium Major after a certain quantity of their gunpowder had been seized: "We have not been keeping the above mentioned gunpowder to use it treacherously against your Lordships, but for our common enemies, enemies of the Christiandom". Ragusans have put themselves in place of Venetians dissatisfied because of the disruption of their trade due to the war with Turks 1571-1573. Papal intentions to fill treasury constantly protected Jewish merchants from the Levant, calling at the Pope's port of Ancona. Due to frequent attacks by Christian pirates, Jews threatened with withdrawal in 1586, and thus Pope Sixto V (of Croatian origin) decreed that neither the Jews nor the Christians trading with Turks should be hindered in any way, with the exception of contraband. ${ }^{133}$

\footnotetext{
132 Tadić 1931c: 8.

133 Bracewell 1997: 34, 104, 165, 202, 207.
} 
The Herzegovinian sandžak-bey asked master shipbuilders from Ragusa to build 5 fustas in Obrovac, but Venetians advised Ragusans in 1569 not to send them to Turks for "if they were built, the said fustas would inflict more harm to the Ragusans than to others". A Ragusan Marin Restić was a political émigré in the service of the rulers of the Italian peninsula as well as the Uskoks' collaborator. Uskoks had planned uprisings in the Balkans for the Duke of Savoy (according to some Ragusan reports). Restic himself was the commander of 10 Uskok boats at the beginning of May 1612 and so the cautious Ragusan Government appointed Pavo Gundulić Captain of [Ragusan] islands, who was able to mobilize 1.000 men from Ragusan islands. Restić was banned from staying on the territory of the Venetian Republic and his capture together with Uskoks would mean the same treatment as for Uskoks themseves. ${ }^{134}$

Uskoks "broke in" into Ragusan villages, seized and looted Ragusan ships on their way back from the Italian peninsula and hindered the communications in the Ragusan hinterland, namely smaller boats for local transport. Uskoks emerged near Ston in spring 1604, ransacking villages in Herzegovina and inflicting damage on some Ragusan peasants, and so the Ragusans sent Pavo Gundulić to the Austrian archduke Ferdinand, who had protested against Uskoks in September, referring to the Emperor's decree (1595) whereby uskok ships were banned from Ragusan territorial waters. According to some information in Ragusa (June $28^{\text {th }}, 1605$ ), eight uskok ships were hidden in some coves on the island of Mljet. On Ss. Peter's and Paul's (June 29 $\left.9^{\text {th }}\right)$, Uskoks (300 of them) sailed by Ragusa in the evening, came ashore near Kupari (Župa dubrovačka), and carried on to Trebinje (nowadays Bosnia and Herzegovina) in the evening. After looting and capturing locals, Uskoks carried on to Slano, where they waited for possible ransom from June $30^{\text {th }}$ till July $2^{\text {nd }}, 1605$ for people and goods (from Herzegovinians and Turks). They set out towards Vratnik on July $3^{\text {rd }}, 1605$ where they encountered a Venetian trireme and 7 Albanian ships carrying a Turkish envoy, on his way from Venice to Ragusa, and these Venetian ships did not act against Uskoks with hostility. Uskoks reappeared in Slano (after 8 days), and in their habitual manner crossed over to Herzegovina in the night, looting some houses in Ravno, then sailed north with the captives and booty plentiful, attacking some locals on Pelješac and killing three local captains. Persistent Ragusan pleas had some effect on Uskoks, who eased their attacks in 1606, but they looted a village near Klek in March. Penetration into Herzegovina by two ships in July was intercepted by five Albanian ships (in Venetian service) aided by Turks from Herzegovina to wedge Uskoks who had eight of their own ships coming to their assistance. Some Ragusan villages were ransacked again. The old route to penetrate into Herzegovina (in the bay between Mali Ston and Neretva) was used by Uskoks again in March, 1610. Four uskok ships launched an attack on two Ragusan ships (galleons, on return trip from Ancona) under the command of captains Kopšić and Gruica in April 1610 , when many Ragusan tradesmen were robbed in the amount of 30.000 ducats. Both

134 Stanojević 1973: 74, 239. 
captains of looted ships were sentenced to 8 months' imprisonment, and some sailors to 5 years (i.e. rowing in chains on Ragusan warships on their launching and rigging), while a captain lost his licence for having been involved in the looting himself. This uskok action was led by Miho Baračević, Vicko Hreljanović (Hreljić), Đurica hajduk (Hajduković) and the army flag-bearer. The Ragusan Government wrote, both to the general in Zagreb and captain in Senj, regarding salvage of goods seized from the galleon, and so the emissary of the damaged tradesmen got a certain reimbursement. Ragusans suffered heavy damage in 1612 when coastal settlements of Pelješac were ransacked, wine looted and smaller boats stolen and later sold all over Dalmatia. The last heavy uskok attack took place on April 18 ${ }^{\text {th }}, 1613$ when 11 uskok ships appeared in Ragusan waters and crossed over Rijeka dubrovačka to Popovo polje (they looted the surroundings of Trebinje the following day). The same day, a large vessel with capt. Jakšić with two bother ships were sent on their way to Slano where the uskok ships awaited the looty, Uskoks had gone on to Trsteno and sailed out rowing to the open sea. A part of the booty remained ashore (horses and other livestock), while human spoils on board their ships consisted of 130 souls (mainly Christians from Herzegovina). An uskok boat appeared at the mouth of the River Neretva in January 1614 and looted Slivno. The commander of the unsuccessful pursuit was instructed to eliminate some 20 Uskoks. $^{135}$

The area of Croatian lands, "the scene of conflict between two types of feudalism by new methods" since the $15^{\text {th }}$ century saw the closed "Turkish economy turned into subsistence economy, while war was an entrepreneurship bringing permanent profit". Turkish navy was not modernized, and sultan Suleyman's attempt in 1548 to introduce rifles instead of arrows in the Turkish army was also unsuccessful. Complaints against Uskoks do not describe them as looters, but rather as raiders of a part of a property since "the damaged party" reported "looting" to the rector in order to be acquitted of accusations that they were the uskok-outlaws' harbourers. Likewise, a voluntary assistance in provisions was going on and it also came from lower clergy (Franciscans). Venetians had even recruited Albanians since Croatian soldiers in the Venetian service had refused to take part in conflicts with Uskoks. A decision on moving Uskoks from Senj stipulated that "their warships will be burnt, but not trade ships". Venetians also took part in looting and pirating in uskok war. A similar war (in the pirate manner) was going on from the $16^{\text {th }}$ to the $18^{\text {th }}$ century between Spain, France, The Netherlands and England for trade routes to America. The uskok war was "a means of Austrian pressure on Venetians to allow free trade off Rijeka and Trieste with the Kingdom of Naples and the Papal States", and its efficiency cost Venice 20.000 scudos per month. This war did not respect the principle of religion but that of the state, as absolutism was accepted according to the Machiavellian methods, unlike those wars waged in the $15^{\text {th }}$

135 Tadić 1936b: 13. After the feast, drunken Uskoks attacked from Slano Venetian galleys bound for Šipan in 1605, but Venetians sank "two boats", upon gunfire and rifle firing. During the attack, 40 Uskoks were wounded and 20 Uskoks perished. See: Novak G. 2004a: 61. 
century and the Battle of Lepanto in 1571. The Venetian providore Venier received an order in 1617 to attack Ragusa "as they were plotting with Spain". In fact, the uskok war was for Venice an issue of trade supremacy in the Adriatic since Austria under Archduke Ferdinand advocated free trade for exports of raw materials from Turkey and was losing its military power (similar customs war was waged between France and The Netherlands during 1672-1678). The Archduke had betrayed Uskoks as a means of pressure on Venice, as well as the interests of the Croatian people. The physiocratic movement nurtured the cult of free trade, while Venetian sources depict Uskoks, in a biased and almost autobiographical way, as pirates and hinderers of trade. During conflicts among Christian rulers and pandering with the Turkish Empire, Uskoks were fighting for survival and freedom. ${ }^{136}$

Uskoks did not come to Dubrovnik as enemies only, but some of them were in the service of the Ragusan Republic which needed soldiers and the barabanti-merceneries who spoke in the vernacular (Croatian) language, most frequently from Senj, and who were under the command of their leader, as it was probably prior to the great earthquake (1667) with the commander Juraj Dubravčić from Senj from 1652 until (later) from 1667-1668 Ragusa and its territory were exposed to hajduk attacks and during Candian war Venetians and Turks did not only fight in Candia (Crete), but also in Dalmatia. ${ }^{137}$ Groups or individual mercenaries came to Ragusa either on their own account or sought for in Croatia and in Hungary by Ragusan authorities and they were assigned to ships that were engaged in foreign and local boats smuggling wine. ${ }^{138}$ Soldiers were recruited from the entire territory of the Ragusan Republic (Konavle, Župa dubrovačka, Rijeka, Dubrovačko primorje, the islands in the Ragusan surroundings, Pelješac, Mljet and Lastovo) and their mixing with foreign mercenaries guaranteed reliability of the army. Soldiers were seeing off caravans from Tabor at Ploče outside the City walls to the Turkish border at Ivanica (presently Bosnia and Herzegovina). They were guarding approaches to the City from its walls, kept guard at the city gates, and attentively escorted ships until they disappeared beyond the cliffs of Konavle or behind the island of Mljet in case they had pirate or hostile intentions. ${ }^{139}$

During the Candian war (1645-1669) and also in 1648, Venetians complained to the Venetian Doge, the Pope and the European courts that Ragusans were helping the Ottoman Empire, supplying them with guns, war equipment and with the bumbašigunners. Venetians had stopped near Lastovo on their way to Candia (Crete) in 1651, came ashore on the island with some 150 soldiers and looted arms and money in households, "worse than savages from Africa", as was noted down by the Ragusan Republic in its letter to their envoy Miho Sorgo in Venice. The amount of stolen money came to

\footnotetext{
136 Pederin 1981-1982: 184-190, 192, 197.

137 Vučetić 1913: 10, 12.

138 Macan Tr 1962: 307, 314.

139 Macan To 2001b: 337, 341. This work was also published in: Dubrovački horizonti, year XII, No. 20, Zagreb, 1980: 58-63.
} 
approximately 300 Venetian ducats. The Ragusans asked Miho Sorgo (Sorkočević) in Venice for wood, iron and nails for ships. The pirate fustas (in fact, several of them) from St Mauro and Ulcinj aggravated the Ragusan maritime trade from 1654/1655. ${ }^{140}$

Participation and presence of Ragusan mariners in foreign navies was notable, although mightier was the fact similar to that of the number of foreigners on Ragusan ships. During Franco-Spanish conflicts on Sicily and in the Adriatic (1674-1678), the French party often engaged Croatian sailors as assistance on its ships and thus a French ship (tartana - with her crew of 50 "Sklavoni" - Croats) stopped and seized a Venetian ship (marsigliana) in the Adriatic in 1677, and called at Messina. Ragusan ships enabled transport of the Imperial (German) troops from Trieste to Pescara in 1675. The French even suspected Dalmatians (Croats from Dalmatia) in 1676, who were sailing on trade ships under the flag of St. Mark, and neither did the Spaniards spare them. D'Estrades, the Abbot and the envoy of France to Venice, concluded in March 1677 "that the Serenissima (The Venetian Republic, ob.a.) wished to rule alone in the Adriatic Sea, what could be achieved through total disruption of trade of the small Ragusan Republic, thus ignoring complaints from the Pope whose States were affected through that trade "duel". Arnauld de Pompon, French Minister of foreign affairs, learnt from Abbot d'Estrades in August of 1677 "that Ragusans had recently sent to Naples 400 troopers with their officers, at the request of Spain, and that many others intended to follow them in order to seek jobs in the same place". He commented on "two faced character" of the Ragusans, saying that "they negotiate with everyone at the same time", even with Turks. Venetians resolved their own conflicts with foreign manpower and so in October 1679 (conflict over Montferrat) the majority of 4000 men were Greeks and Dalmatians (Croats). The predominance of Croatian (Dalmatian) soldiers in Venetian armed forces is reflected in 6 cavalry detachments of "Sklavoni" (Croats, 600 of them), while the Venetian infantry comprised 900 Italians, 1.300 Germans and French, and 2.500 "Sklavoni" (Croats). According to information given by Louvigny d'Orgemont, the intermediary of King Louis XIV in Venice, at disembarkation of Venetian army at Lepanto and Patras (July 1687), there were 11.000 soldiers for the battle with Turks, where more than one half were soldiers from "sklavonic" and Albanian militias and Dalmatians called by them Capeletti, who were considered good soldiers". Jérome de Pontchartrain, French Naval secretary, expressed concern in 1704 "because of the fact that foreign ships on their route to the Levant were sailing under the flag of Jerusalem" (the knights of St. John of Jerusalem, in fact, from Malta) or Ragusa, and that "to the detriment of the French flag which was not sought after as much". The Ragusan flag brought safety to the foreign ships sailing to Egypt and trading in Alexandria. ${ }^{141} \mathrm{~A}$ lot of permanently or temporarily settled émigrés (7\%) from the freedom oriented Ragusan Republic lived in Venice: mostly from the City of Ragusa but also from the

\footnotetext{
$140 \quad$ Vučetić 1896: 13, 19-20, 25.

141 Orešković 2000: 178, 181, 183, 187, 189, 233.
} 
surrounding settlements in the Republic of St Blaise (Ston, the peninsula of Pelješac, Župa dubrovačka, the Elaphite islands and some other). Venetian quarters of Castello known for its waterfront Riva degli Schiavoni (more than $500 \mathrm{~m}$ long), known as the "Croatian waterfront", or "Riva od Hrvatov", which had been the most suitable berthing place through centuries. The square/street Corte Sabbioncella was named after Dominik (Domenico) Sabbioncello, an émigré carpenter (marangun, marangon) from the peninsula of Pelješac (Ital. Sab(b)ioncello) in the Venetian arsenal in the second half of the $16^{\text {th }}$ century (The Pelješac Square/Street was recorded in publications of more recent period, through a slip, as Corte Sabbionera). Some present streets in Venetian quarters of Dorsoduro still bear the names of Calle Ragusei and Calle larga Ragusei (after Ragusans), and it was earlier that the two bridges had displayed the Ragusan sign (Ponte dei Ragusei). Marin Držić (1508-1567), the renowned Ragusan playwright of the Renaissance, was buried in the Dominican church of St John and Paul (SS. Giovanni e Paulo, S. Zuanne Polo, Zanipolo) in Venice. ${ }^{142}$

In the period 1520-1623, the landed patricians (nobility) invested in their colonies (in a wider hinterland, the amount of 3.629.221 ducats (58\%) out of the total of 6.258.107 ducats.) ${ }^{143}$ The Ragusan financial investments abroad (Naples, Rome, Venice, Genoa, Messina, Palermo) from 1575 up to 1577 were over 250.000 Ragusan ducats, while from 1583-1588 they were over 400.000 ducats (profits exceeded 20.000-29.000 ducats). Foreign investments came to over 653.000 ducats in 1601, while in 1621 their amount was over 698.000 ducats (profits from 37.000 to 44.000 ducats). ${ }^{144}$ Thus, the Ragusan investments in "Monte di Pieta" (public pawnshops-charitable institutions) of the Italian peninsula 1575-1577 amounted to the principle of 57.957 Roman scudos or 46.366 Ragusan ducats with an income of 4.309 Roman scudos or 3.447 Ragusan ducats (Rome), 124.026 Neapolitan ducats or 105.423 Ragusan and (annual) income of 11.779 Neapolitan ducats or 10.012 Ragusan ducats (Naples), 71.338 Venetian ducats or 60.673 Ragusan ducats and the revenue of 6.025 Venetian or 5.121 Ragusan ducats (Venice), 33.102 Genoese scudos or 34.757 Ragusan ducats with an income of 1.216 Genoese scudos or 1.277 Ragusan ducats (Genoa), and 6.666 Sicilian scudos or 4.999 Ragusan ducats with the profit of 600 Sicilian scudos or 450 Ragusan ducats (Sicily). For a period in 1621, the amounts ranged from 108.100 Roman scudos or 116.207 Ragusan ducats and the revenue of 5.863 Roman Scudos or 6.303 Ragusan ducats (Rome), 596.984 Neapolitan ducats or 552.210 Ragusan ducats with profit of 31.002 Neapolitan or 28.677 Ragusan ducats (Naples), 962 Venetian or Ragusan ducats with a

142 Čoralić 2003: 15, 213-214, 222, 233; Čoralić 1994a: 49-50; Čoralić 1994b: 37; Čoralić 1998: 60-61, 66, 74 .

143 Zlatar 2007: 132.

144 Di Vittorio 2002: 19-20; Di Vittorio 2001: 19. While private investments (capitals) of the Ragusan Republic invested in various city-states on the Italian peninsula amounted to 401.994 ducats from $1583-1588$, they reached 653.632 ducats in 1601 , while in 1621 they amounted in general even to 698.179 ducats with proportional (annual) revenues. See: Di Vittorio 1983: 32. 
revenue of 67 Venetian or Ragusan ducats (Venice), 24.000 Genoese scudos or 28.800 Ragusan ducats with a revenue of 1.200 Genoese scudos or 1.440 Ragusan ducats (Genoa). Ragusans (85 of them) collected revenue in the period 1575-1577 from 128 business activities, while in 1621 there were as many as 234 activities carried out (by 172 individuals). ${ }^{145}$ The merchant ships of Ragusa generated income from 180.000 to 270.000 ducats during the $17^{\text {th }}$ century. ${ }^{146}$ It is supposed that there were 300.000 ducats kept in the safe of the Ragusan state, as well as other currencies (their value amounting to 100.000 ducats) after the great earthquake, as well as the charity funds, which was very difficult to find in any town on the Italian peninsula (Rome, Milan and Genoa were not taken into account). ${ }^{147}$

Considering the maritime and trading "duel" between the Republic of St Blaise (Dubrovnik) and the Republic of St Mark (Venice), in connection with the barge from Split towards the interior of the Balkan Peninsula which was established by Venetians in order to do harm to Ragusans (in the long run without success), "victory" of the Ragusans is completely understandable, logical and natural since manifested in safeguarding the priority of the maritime trade in the Adriatic Sea and partly in the Levant. ${ }^{148}$

Historical experience offers an approach to the possibilities and impediments presented by the sea to all those wishing to "make Europe". The sea, in this case the Mediterranean and specially the Atlantic, enables useful observations: some may agree with Edgar Morin that it is 'hard to see Europe from Europe itself even from a defined point of Europe. Certain distance is needed, and the sea offers one. In his voyage to Brazil, Jean de Léry noticed: Those that have not been at sea... have seen only a half of the world. ${ }^{149}$ Let us add that they have, in fact, seen only its smaller part or one third of it. And, in addition, it was relatively superfluous. Jacques le Goff once made a statement that he was ashamed for not being better acquainted with the Croatian naval history of the Middle Ages, and let us add that the history of the world in world proportions without the less known Croatian shipping history was only superfluous in the true sense of the word.

\footnotetext{
145 Di Vittorio 1977: 602, 605, 625.

146 Di Vittorio 1977: 604; Tadić 1962: 106. Text by the same author is cited as: Jorjo Tadić, Ragusa e il suo porto nel Cinquecento, Archivio Storico Pugliese, Anno XIV, Fascicolo III-IV, (Bari, 1960): $15-51$.

147 Pederin 1996: 197.

148 Josip Luetić 1987: 28.

149 Mollat du Jourdin 1993: 205, 207.
} 


\section{Bibliography}

1. Anselmi, S. 1976. Schiavoni e Albanesi nell' agricoltura Marchigiana dei secoli XIV e XV, Estratto dal Rivista di Storia dell' Agricoltura, a. XVI, n. 2, Firenze: 9-10.

2. Antoljak, S. 1944a. Trgovačke veze Dubrovnika s Turcima, Ugovor iz godine 1442. bio je temelj cielom dubrovačkom trgovačkom životu i plovidbi, (Merchant connections of Dubrovnik and Turks, Agreement from 1442 was the basis of the entire Ragusan trading life and sailing), Gospodarstvo, year IV, No. 47, Zagreb: (9).

3. Antoljak, S. 1944b. Cvat dubrovačke trgovačke mornarice, Gospodarstvo, year IV, No. 157, Zagreb: 9.

4. Antoljak, S. 1944c. Smetnje dubrovačkoj trgovini u XVII. vieku, Mletačka republika nastojala je uviek da uguši svaku stranu trgovinu na Jadranu, Gospodarstvo, year IV, No. 192, Zagreb: 10.

5. Antoljak, S. 1944d. Trgovački odnosi izmedju Dubrovnika i Venecije, Gospodarstvo, year IV, No. 204, Zagreb: (9).

6. Appendini, F. M. 1803. Notizie istorico-critiche sulle antichità, storia e letteratura de' Ragusei, Tomo II, Dalle stampe di Antonio Martecchini, Ragusa: 201.

7. Babić, I. 1991. U očima drugih, Marija Rožman-Kandido "Francuski putopisi kroz Dalmaciju od prvog križarskog pohoda do kraja 18. stoljeća", (Suggestion for publishing), Slobodna Dalmacija, year XLIX, (Monday, August $5^{\text {th }}, 1991$.), Split: 20.

8. Bačić, V. A. 1941. Dubrovački brodovi u doba procvata dubrovačkog pomorstva u XVI vijeku, Izdanje Knjižare Vasić i Horvat, Zagreb: 30, 32.

9. Bačić, V. A. 1948. San Blas y su Republica Ragusa Dubrovnik, Ensayo Historico por el Cap. B. (written by: Dr Vilim Bačić od Rečine, lawyer in Lima), Fiesta de San Blas, Imp. "El Cóndor", Lima: 29.

10. Bašić, Đ. 2003. Dva priloga iz pomorske prošlosti starog Dubrovnika, ("Savršeni brod" Vice Martolosića/“Perfect ship” by Vice Martolosic), Dubrovački horizonti, year XXXIII, No. 42, Zagreb: 85-86.

11. Bašić, Đ. 2004. Dubrovački pomorski rodovi Martolosići i Mažibradići, Zbornik Dubrovačkih muzeja, I, Dubrovnik: 192-193.

12. Bašić, Đivo. 2007. Bitka kod Lepanta 7. listopada 1571. godine, (Battle of Lepanto, October $7^{\text {th }}$, 1571), Mogućnosti, year LIV, No. 10-12, Split: 143-156.

13. Bošnjak, M. 1952. Dubrovačko pomorstvo u literaturi, Dubrovačko pomorstvo, (Zbornik), Dubrovnik: 455, n. 3-5.

14. Boxer, C. R. 1930. The Journal of Maarten Harpertszoon Tromp, Anno 1639, Cambridge University Press, Cambridge: 66, n. 1.

15. Bracewell, C. W. 1997. Senjski uskoci, Piratstvo, razbojništvo i sveti rat na Jadranu u šesnaestom stoljeću, (The Uskoks of Senj, Piracy, Banditry and Holy War in the Sixteenth-century Adriatic, Cornell University Press, 1992), Barbat, Zagreb: 34, 104, 165, 202, 207.

16. Braudel, F. 1997. Sredozemlje i sredozemni svijet u doba Filipa II., Vol. I, Antibarbarus, Zagreb: 129.

17. Brown, O. - Whittaker, J. 2000. A Treasure Lost: the Spanish Wreck in Tobermory Bay, Brown \& Whittaker Publishing, Tobermory: 5, 15, 17-18, 27.

18. Carter, F. W. 1972. Dubrovnik (Ragusa), a Classic City-State, London - New York: Seminar Press.

19. Cipolla, C. M. 1996. Conquistadores, pirati, mercatanti, La saga dell'argento spagnuolo, Il Mulino, Bologna: 7, 24-25, 28-29, 54, 66.

20. Coniglio, G. 1990. Declino del viceregno di Napoli (1599-1689), Quaderni della Facoltà di Scienze Politiche 34, Vol. III, Università di Napoli, Giannini Editore, Napulj: 1439-1441.

21. Crijević Tuberon, L. (Lvdovici Tvberonis Dalmatae Abbatis). 2001. Komentari o mojem vremenu (Commentarii de temporibus suis), Hrvatski institut za povijest, Zagreb: 227.

22. Cvjetković, B. 1927. Miho Pracat, brodovlasnik, pomorski kapetan i veliki dobrotvor, Jadranska straža, year V, No. 3, Split: 63-66.

23. Cvjetković, B. 1928. Razvoj Dubrovnika, Stari i novi Dubrovnik, Naši gradovi na moru, (Reprinted from "Nova Evropa", Vol. XVII), Zagreb: 20-21, 27, 30.

24. Čoralić, L. 1994a. Dubrovčani u Veneciji od XIII. do XVIII. stoljeća, Anali Zavoda za povijesne znanosti HAZU u Dubrovniku, vol. XXXII, Dubrovnik: 49-50. 
25. Čoralić, L. 1994b. Prilog poznavanju nazočnosti i djelovanja doseljenika sa Elafitskih otoka u Veneciji od XV. do XVIII. stoljeća, Dubrovački horizonti, year XXV, No. 34, Zagreb: 37.

26. Čoralić, L. 1998. Od hrvatske obale do dubrovačke ulice: hrvatski prinosi mletačkoj toponomastici, Kolo, (Review of Matica hrvatska), year VIII, No. 4, Zagreb: 60-61, 66, 74.

27. Čoralić, L. 2003. Hrvatski prinosi mletačkoj kulturi, Odabrane teme, Dom i svijet, Zagreb: 15, 213-214, 222, 233.

28. Čralić, L. 2004. Tragovima Hrvata u južnoj Engleskoj, Argosy, dubrovačke karake, Slobodna Dalmacija, year LXI, No. 19010, (Wednesday, January 14 $\left.{ }^{\text {th }}, 2004\right)$, Split: 62.

29. Dadić, Ž. 1991. Egzaktne znanosti hrvatskog srednjovjekovlja, Globus, Zagreb: 136, 138.

30. Deanović, M. 1952. Naš prvi pomorac pisac Dubrovčanin Nikola Sagroević (Sagri), Dubrovačko pomorstvo, (Zbornik), Dubrovnik: 459, 461.

31. Di Vittorio, A. 1977. Gli investimenti finanziari Ragusei in Italia tra XVI e XVIII Secolo, Rassegna Economica, (Publicazione bimestrale del Banco di Napoli), /Estratto/, Anno XLI, N. 3, (Maggio-Giugno), Napoli: 602, 605, 625.

32. Di Vittorio, A. 1983. Finanze e moneta a Ragusa nell'età delle crisi, Giannini editore, Napoli: 32.

33. Di Vittorio, A. 2001. Tra mare e terra, Aspetti economici e finanziari della Repubblica di Ragusa in età moderna, Caccuci Editore, Bari: 19.

34. Di Vittorio, A. 2002. Između mora i kopna, Gospodarsko-financijski aspekti Dubrovačke Republike u novom vijeku, PGM Ragusa, Dubrovnik: 19-20.

35. Elliott, J. H. 1986. The Count-Duke of Olivares, the Statesman in the Age of Decline, Yale University Press, New Haven - London: 550-551.

36. Eyüp Özveren, Y. 2000. Shipbuilding 1590-1790, Review, A Journal of the Fernand Braudel Center, Vol. XXIII, No. 1, Binghamton University, Binghamton: 21-22, 50.

37. Fejić, N. 1983. Dubrovčanin Benko Kotruljević pred sudom kraljice Marije Aragonske u Barceloni, Istorijski časopis (Revue Historique), Books XXIX-XXX, (1982-1983), Istorijski institut (Institut d'histoire), Beograd: 77-83.

38. Fernández-Armesto, F. 2008. Maritime History and World History, in: Maritime History as World History, (ed. Daniel Finamore), Gainesville: University Press of Florida.

39. Foretić, V. 1952a. Iz povijesti korčulanske brodogradnje, Brodogradnja, year III, No. 2, Zagreb: 86-87.

40. Foretić, V. 1952b. Iz historije korčulanske brodogradnje, Brodogradnja, year III, No. 3, Zagreb: 139.

41. Foretić, V. 1952c. Iz historije korčulanske brodogradnje, Brodogradnja, year III, No. 4, Zagreb: 179.

42. Foretić, V. 1960. Činjenice i pretpostavke, Veze starih Dubrovčana s novootkrivenim zemljama i njihovo iseljavanje, (Facts and suppositions, Connections of old Ragusans with newly discovered lands and their emigration), Matica, Iseljenički kalendar, Zagreb: 149.

43. Foretić, V. 1962. Argosy, Dubrovački vjesnik, year XIII, No. 613, (Tuesday, July 10 ${ }^{\text {th }}, 1962$ ), Dubrovnik: 4.

44. Foretić, V. 1980. Povijest Dubrovnika do 1808., (Od osnutka do 1526.), $1^{\text {st }}$ part, Nakladni zavod MH, Zagreb: 176-177.

45. Fusko, P. 1990. Opis obale Ilirika, (Compiled and translated: Bruna Kuntić-Makvić; Preface and comment: Miroslav Kurelac), Book XIX, Latina et Graeca, Zagreb: 104-105.

46. Gelcich, G. 1889. I Conti di Tuhelj, Contributi alla Storia della Marina Dalmata ne' suoi rapporti colla Spagna, Ottavo Programma dell' I. R. Scuola Nautica di Ragusa per l'anno scolastico 188889., Edito dalla Direzione dell' I. R. Scuola Nautica, Dubrovnik: 100, 107.

47. Goodman, D. 1997. Spanish naval power 1589-1665, Cambridge University Press, Cambridge: 117-118.

48. Hardie, R. P. 1912. The Tobermory Argosy, a Problem of the Spanish Armada, Oliver and Boyd, (Tweeddale Court, Edinburgh), London: 43.

49. Hrabak, B. 1956. Dubrovnik i rodski pirati, Istoriski glasnik, 2, Beograd: 80, 83, 89.

50. Hrabak, B. 1980. "Dubrovačko" srebro u Italiji i Kataloniji u XIV, XV i XVI veku, Istorijski glasnik, No. 1-2, Beograd: 74-75.

51. Ivanović, N. Š. 1931a. Crtice iz dubrovačke prošlosti, Jugoslavenski pomorac, year XI, No 14, (July $15^{\text {th }}, 1931$ ), Zagreb: 2. 
52. Ivanović, N. Š. 1931b. Crtice iz dubrovačke pomorske prošlosti, Narodna svijest, year XIII, No. 32, (August $\left.5^{\text {th }}, 1931.\right)$, Dubrovnik: 4.

53. Jenkins, E. H. 1973. A History of the French Navy, from Its Beginnings to the Present Day, Macdonald and Jane's, London: 40.

54. Kirsch, P. 1990. The Galleon, The Great Ships of the Armada Era, Conway Maritime Press, London: 3-4, 108.

55. Kojaković, V. 1930. Stari Dubrovnik i Španija, Jedan prilog dubrovačkoj diplomaciji, Narodna svijest, year XII, No. 5, (Feb $\left.5^{\text {th }}, 1930\right)$, Dubrovnik: 4.

56. Kostić, V. 1972. Ragusa and the Spanish Armada, Balcanica, III, Annuaire de L'Institut des Etudes Balkaniques, Beograd: 196-235.

57. Kostić, V. 1975. Dubrovnik i Engleska 1300-1650, (Dubrovnik and England 1300-1650), Posebna izdanja, Book CDLXXXVIII, Odelenje jezika i književnosti, book 26, SANU, Beograd: 111, 280.

58. Kostić, V. 1977. Ragusa and the Spanish Armada, Dubrovnik's Relations with England, A Symposium (April 1976), Department of English, Faculty of Philosophy, University of Zagreb, Zagreb: 47-61.

59. Kostić, V. 2007. Sličice iz života dubrovačkih trgovaca u Londonu u vrijeme kralja Henryja VIII., Anali Zavoda za povijesne znanosti HAZU u Dubrovniku, Vol. XLV, Zagreb - Dubrovnik: 119, 125.

60. Kotruljević, B. 1989. Della mercatvra et del mercante perfetto, O trgovini i o savršenom trgovcu, (Translation: Žarko Muljačić), Publisher: DTS (Dubrovački trgovačko-turistički sistem), Dubrovnik: 153-154, 165, 199.

61. Kotruljević, B. 2005a. De navigatione, O plovidbi, (compiled and translated by Damir Salopek), Ex libris, Zagreb: 84-85, 134-135.

62. Kotruljević, B. 2005b. Knjiga o umijeću trgovanja, (Il libro dell 'arte di mercatura), (Translation from Italian: Žarko Muljačić), Binoza Press, Zagreb: 44, 48, 64.

63. Krasić, S. 1971. Serafin Razzi i Dubrovnik, Dubrovački horizonti, year III, pp. 7-8, Dubrovnik: 26-30.

64. Krasić, S. 1998. Djela likovne umjetnosti u Dominikanskom samostanu u Dubrovniku u XV. i XVI. stoljeću, Dubrovnik, (Review for literature and science), N. s., year IX, No. 2-3, Dubrovnik: 242-243.

65. Krasić, S. - Razzi, S. 1999. Povijest dubrovačke metropolije i dubrovačkih nadbiskupa (X.-XVI. stoljeća), Biskupski ordinarijat Dubrovnik - Crkva u svijetu Split, Dubrovnik: 74-75.

66. Krasić, S. 2002. Dominikanski samostan u Dubrovniku, Povijesno-umjetnički prikaz, Dominikanski samostan sv. Dominika, Dubrovnik: 65-66.

67. Krekić, B. 1961. Dubrovnik (Raguse) et le Levant au Moyen âge, École Pratique des HautesÉtudes - Sorbonne, VIe Section, Documents et recherches, V, Mouton \& Co, Paris - La Haye: 294.

68. Krizman, B. 1957. Diplomati i konzuli u starom Dubrovniku, IBI, (Company for publishing, selling and distribution of books), Zagreb: 24-25, 33.

69. Lane, F. C. 1992. Venetian Ships and Shipbuilders of the Renaissance, Johns Hopkins University Press, Baltimore - London: 60, 62-63, 212.

70. Latham R. - Matthews W. 1970. The Diary of Samuel Pepys, Vol. III. (1662), G. Bell and Sons Ltd, London: 8, n. 3.

71. Levental, Z. 1989. Britanski putnici u našim krajevima od sredine XV do početka XIX veka, Gornji Milanovac: 57, 69, 74, 146.

72. Liber Statutorum doane Ragusii MCCLXXVII / Knjiga odredaba dubrovačke carinarnice1277 / Book of Ordinances of the Ragusan Customs Office 1277, (Transcripsit, redegit et traduxit / Transcribed, compiled and translated by: Josip Lučić), Ragusii / Dubrovnik, 1989: 9.

73. Lisičar, V. 1930. Još o Mihu Pracatu, Narodna svijest, year XII, No. 45, (Nov.12 ${ }^{\text {th }}, 1930$.), Dubrovnik: 4.

74. Lisičar, V. 1932. Lopud, Eine Historische und Zeitgenössische Darstellung, Dubrovačka hrvatska tiskara, Dubrovnik: 79-85.

75. Lisičar, V. 1933. Dr. Jorjo Tadić: Miho Pracatović-Pracat, Narodna svijest, year XV, No. 23, (June $\left.7^{\text {th }}, 1933\right)$, Dubrovnik: 1 .

76. Lučić, J. 1951. Prilog brodogradnji u Dubrovniku u drugoj polovini XIV. stoljeća, Historijski zbornik, year IV, No. 1-4, Zagreb: 137.

77. Lučić, J. 1977. Prilike u Dubrovniku 1510. do 1514. i ustanak na Hvaru, Radovi Instituta za hrvatsku povijest, 10, Sveučilište u Zagrebu, Zagreb: 358-359, 361. 
78. Lučić, J. 1988a. Dubrovački ljetopis od osnutka do danas, Dubrovački horizonti, year XX, No. 28, Zagreb: 93, 100.

79. Lučić, J. 1988b. O kartografiji u Dubrovačkoj Republici, Anali Zavoda za povijesne znanosti JAZU u Dubrovniku, sv. XXVI, Dubrovnik: 127.

80. Lučić, J. 1991a. Prilike u Dubrovnik 1510. do 1514. i ustanak na Hvaru, in: Dubrovačke teme, Nakladni zavod Matice hrvatske, Zagreb: 236-239, 242.

81. Lučić, J. 1991b. Povijest Dubrovnika u djelima Ivana Luciusa, in: Dubrovačke teme, Nakladni zavod Matice hrvatske, Zagreb: 362, 370.

82. Lučić, J. 1991c. O najranijim vezama Dubrovnika s Engleskom i Španjolskom, in: Dubrovačke teme, Nakladni zavod Matice hrvatske, Zagreb: 491.

83. Lučić, J. 1991d. Dubrovački ljetopis od osnutka do danas, in: Dubrovačke teme, Nakladni zavod Matice hrvatske, Zagreb: 516, 529.

84. Lučić, J. 1997. O kartografiji u Dubrovačkoj Republici, in: Dubrovačko povijesno iverje, Matica hrvatska, Dubrovnik: 184.

85. Luetić, J. 1952a. Dubrovački pomorac potkralj Meksika (u XVI. stoljeću), Čuvar Jadrana, year V, No. 222, Split: 4.

86. Luetić, J. 1952b. Pomorac i diplomat Vice Bune, Anali Historijskog instituta u Dubrovniku, year I, Vol. I, Dubrovnik: 257, 265-266.

87. Luetić, J. 1954. Model "Šambeka” u Pomorskom muzeju u Dubrovniku, Muzeji, (Museologicalconservation review), 9, Zagreb: 75-79.

88. Luetić, J. 1958. Grip - zaboravljeni tip našeg jedrenjaka, Vesnik, 5, Vol. I, Vojni muzej JNA, Beograd: 213-218.

89. Luetić, J. 1959a. Dubrovački galijun druge polovine XVI. stoljeća, Anali Historijskog instituta u Dubrovniku, year VI-VII (1957-1959), Dubrovnik: 129-141.

90. Luetić, J. 1959b. Dubrovački pomorac potkralj Meksika u XVI. stoljeću, Naše more, year VI, No. 6, Dubrovnik: 285-286.

91. Luetić, J. 1959c. Galijica Dubrovačke Republike, Mornarički glasnik, year IX, No. 1, Split: 53-63.

92. Luetić, J. 1960a. I jedrenjacima smo prednjačili u pomorskom svijetu (Zaboravljeni tipovi naših starih brodova), Pomorstvo, year XV, No. 8-9, Rijeka: 355-359.

93. Luetić, J. 1960b. "Prove di fortuna" di navi veneziane a Ragusa, Estratto dal: Bollettino del'Istituto di Storia della Società e dello Stato, II (1960), Fondazione Giorgio Cini, Centro di cultura e civiltà, Venezia: 215.

94. Luetić, J. 1964. Brodovlje Dubrovačke Republike XVII stoljeća, Građa za pomorsku povijest Dubrovnika, Book 3, JAZU - Pomorski muzej Dubrovnik, Dubrovnik: 29, 85-89.

95. Luetić, J. 1966a. Dubrovački galijun - jedrenjak svjetskog glasa, Naše more, year XIII, No. 6, Dubrovnik: 290-293.

96. Luetić, J. 1966b. Dubrovački galijun - najtipičniji slavenski jedrenjak XVI stoljeća, Mornarički glasnik, year XVI, No. 2, Beograd: 269-278.

97. Luetić, J. 1966c. Ormanica - naš tip ratnog broda, Vojnopomorski ogledi, year I, No. 1, Published by Vojnopomorski muzej RM, Split: 71-74.

98. Luetić, J. 1967. Najmanji tip našeg ratnog broda u prošlosti - ormanica, Dubrovnik, (Review for literature, art, science and questions of society), year X, No. 1, Dubrovnik: 130-132.

99. Luetić, J. 1969a. O gripu - našem jedrenjaku u prošlosti, 10 godina Više pomorske škole u Dubrovniku, 1959-1969, Dubrovnik: 109-115.

100. Luetić, J. 1969b. 1000 godina dubrovačkog brodarstva, Zora, Zagreb: 16-17.

101. Luetić, J. 1971a. O nekim starim tipovima dubrovačkih jedrenjaka, Dubrovnik, (Review for literature, art, science and questions of society), year XIV, No. 3, Dubrovnik: 93-97.

102. Luetić, J. 1971b. 1.000 pomorskih havarija prijavljenih u Dubrovniku 1629-1811, Spasavanje ljudskih života na moru (Naučne rasprave), Pomorska biblioteka, vol. 23, Published by Mornarički glasnik, Beograd: 35.

103. Luetić, J. 1972. Havarije bokeljskih brodova u spisima Pomorskog konzulata - Skupštine Dubrovačke Republike od 1629. do 1811. god., Godišnjak Pomorskog muzeja u Kotoru, year XX, Kotor: 134.

104. Luetić, J. 1975. Galijica Dubrovačke Republike, in: Modeli naših brodova, Publisher: "Čuvar Jadrana", Split: 90-98.

105. Luetić, J. 1976a. Filjuga, Najznačajniji operativni brod dubrovačke države (druga pol. 17-19. 
st.), Anali Historijskog odjela Centra za znanstveni rad JAZU u Dubrovniku, Vol. XIII-XIV, Dubrovnik: 95-116.

106. Luetić, J. 1976b. Su alcuni tipi antichi di navi Ragusee, Estratto da: Bollettino dell'Atlante linguistico Mediterraneo, 13-15, (1971-1973), Leo S. Olschki Editore, Firenze: 459-463.

107. Luetić, J. 1977a. English mariners and ships in the seventeenth century Dubrovnik, Dubrovnik's Relations with England, A Symposium (April 1976), Department of English, Faculty of Philosophy, University of Zagreb, Zagreb: 219-221, 232.

108. Luetić, J. 1977b. Grip - najdjelotvorniji operativni tip broda pučkih ustanika Matija Ivanića, Radovi, 10, Institut za hrvatsku povijest, Zagreb: 167-178.

109. Luetić, J. 1978. English mariners and ships in seventeenth-century Dubrovnik, The Mariner's Mirror, Vol. 64, No. 3, (August), London: 277-278.

110. Luetić, J. 1979. Prijave pomorskih havarija mletačkih brodova u Dubrovačkoj Republici, Iz djelatnosti "Pomorskog konzulata - skupštine" dubrovačke države, Naše more, year XXVI, No. 4, Dubrovnik: 166.

111. Luetić, J. 1982a. Grip, ormanica, galijica i filjuga - najdjelotvorniji naoružani borovi s kojima su naši pomorci branili svoju obalu u prošlosti, Mogućnosti, year XXIX, No. 8-9-10, Split: 756-769.

112. Luetić, J. 1982b. Ratna mornarica Dubrovačke Republike na obrani svoje obale u 17. stoljeću, Naše more, year XXIX, No. 3-4, Dubrovnik: 165-166.

113. [Luetić J.] 1982c. Ugovor o gradnji broda na brodogradilištu u Gružu 1583. godine, Naše more, year XXIX, No. 3-4, Dubrovnik: 168.

114. Luetić, J. 1984a. Galijica - komandni brod ratne mornarice Dubrovačke Republike, Dubrovački horizonti, year XVI, No. 24, Zagreb: 90-92.

115. Luetić, J. 1984b. Pomorci i jedrenjaci Republike Dubrovačke, Nakladni zavod Matice hrvatske, Zagreb: 97-98.

116. Luetić, J. 1987. La marina mercantile della Repubblica di Ragusa nella marineria Mediterranea e Mondiale, Quaderni Stefaniani, No. 6, (Estratto), Istituzione dei Cavalieri di S. Stefano, Pisa: 28.

117. Luetić, J. 1988a. Primorci Lopuda i Slanske Knežije u španjolskoj "Nepobjedivoj armadi” 1588. godine, Zbornik Dubrovačkog primorja i otoka, II, Dubrovnik: 141-149.

118. Luetić, J. 1988b. Ragusei e loro navi nella "Invincibile Armada" (1588), Storia e civiltà, anno IV, fasc. 4 (Dicembre), Roma: 13-14.

119. Luetić, J. 1988c. Spomen uz obljetnicu invazijsko-desantne operacije španjolske "Nepobjedive armade" u kojoj sudjelovahu i Dubrovčani, Naše more, year XXXV, No. 5-6, Dubrovnik: 237240.

120. Luetić, J. 1994. Brodarstvo Republike Hrvatske: Korijeni i dometi, Kaštelanski zbornik, Book 4, Kaštela: 75

121. Luetić, J. 1997. Dubrovački galijun druge polovine XVI. stoljeća, Zbornik Dubrovačkog primorja i otoka, VI, Dubrovnik: 118-128.

122. Macan, Tomislav. 1936. Dubrovačka Republika i Španjolska, Obitelj, (Illustrated Weekly), year VIII, No. 41, Zagreb.

123. Macan, Tomislav. 1983. Pričice i svaštice, (Prsne kosti kokoši kao uzorak za gradnju Pracatovih brodova), Dubrovački horizonti, year XV, No. 23, Zagreb: 157.

124. Macan, Tomislav. 2001a. Pričice i svaštice, (Prsne kosti kokoši kao uzorak za gradnju Pracatovih brodova), Župski puti, Humanitarno društvo Župe dubrovačke - Čibača, Dubrovnik: 358.

125. Macan, Tomislav. 2001b. Sodati Dubrovačke Republike u knjizi i seoskoj predaji, (Soldiers of the Ragusan Republic in books and rural tradition), in: Župski puti, Humanitarno društvo Župe dubrovačke - Čibača, Dubrovnik: 337, 341.

126. Macan, Trpimir. 1962. Dubrovački barabanti u XVI stoljeću, (Ragusan Mercenaries in the $16^{\text {th }}$ c.), Anali Historijskog instituta JAZU u Dubrovniku, year VIII-IX, (1960.-1961.), Dubrovnik: $307,314$.

127. Manken, I. 1960. Dubrovački patricijat u XIV veku, (Das Ragusanische Patriziat des XIV. Jahrhunderts), Special issues (Sonderschriften), Book (Band) CCCXL, Odeljenje društvenih nauka (Klasse für Sozialwissenschaften), Book (Band) 36, SANU (SAWK), Beograd: 368.

128. Marinović, A. 1968. Stari dubrovački zakon o pomorskom osiguranju, Osiguranje i privreda, (Journal for theory and practice of insurance), year IX, No. 6, Zagreb: 21-22.

129. Marinović, A. 1981. Pomorsko osiguranje u starom Dubrovniku, Simpozij o pomorskom osiguranju - Dubrovnik '81, (Dubrovnik, April $21^{\text {st }}$ till $23^{\text {rd }}$ April, 1981.), Zagreb: 12, 15-16. 
130. Marinović, A. 2005. Dubrovačko pomorsko pravo, Ius maritimum Civitatis Ragusii, Book II, Književni krug, Split: 260-261, 303-304, 345-346.

131. Milošević, M. 1977. Grbaljske bune XV stoljeća, Radovi Instituta za hrvatsku povijest, 10, Sveučilište u Zagrebu, Zagreb: 275, 299.

132. Mirkovich, N. 1943. Ragusa and the Portuguese Spice Trade, The Slavonic and East European Review, Vol. XXI, No. 56, American Series II, (1942-3), Menasha, (Wisconsin): 175, 186.

133. Mitić, I. 1965. Španski konzulat u Dubrovniku za vrijeme Republike, Naše more, year XII, No. 3-4, Dubrovnik: 121.

134. Mitić, I. 1969. O političko-ekonomskim vezama Dubrovačke Republike i Napulja, Pomorski zbornik, Book 7, Zadar: 485-505.

135. Mitić, I. 1970. Nadzornik oružanih snaga i guverner oružja XVII-XIX. stoljeća u Dubrovačkoj Republici, Anali Historijskog instituta JAZU u Dubrovniku, year XII, Dubrovnik: 277-296.

136. Mitić, I. 1972. O značenju prijateljskih veza starog Dubrovnika s Napuljem, Naše more, year XIX, No. 3-4, Dubrovnik: 120-121.

137. Mitić, I. 1973a. Konzulati i konzularna služba starog Dubrovnika, Historijski institut JAZU u Dubrovniku, Dubrovnik: 37, 40, 50, 54.

138. Mitić, I. 1973b. O poslovima dubrovačkog vice-konzula u Napulju krajem XVIII stoljeća, Naše more, year XX, No. 4-5, Dubrovnik: 192-194.

139. Mitić, I. 1976. Za Serenissimu - Dubrovnik samo komuna, nikad Republika, Dubrovnik, year XIX (XXII), No. 5, Dubrovnik: 65-69.

140. Mitić, I. 1978. Ptice za lov kao poklon Dubrovačke Republike vladaru Napulja, Anali Historijskog odjela Centra za znanstveni rad JAZU u Dubrovniku, Vol. XV-XVI, Dubrovnik: 113-135.

141. Mitić, I. 1984. Porijeklo imena broda “Argosy”, Dubrovački vjesnik, year XXXV, No. 1781, (December $\left.8^{\text {th }}, 1984\right)$, Dubrovnik: 6.

142. Mitić, I. 1985a. Neke značajke iz pomorsko trgovačke prošlosti Dubrovačke Republike, (I. Dubrovački brod - "argosy"), Dubrovački horizonti, year XVII, No. 25, Zagreb: 59-60.

143. Mitić, I. 1985b. Politički i pomorsko-trgovački odnosi Dubrovačke države - Republike i Napuljske kraljevine od XIII do sredine XVII st., Naše more, year XXXII, No. 1-2, Dubrovnik: 57-58.

144. Mitić, I. 1985c. Politički i pomorsko-trgovački odnosi Dubrovačke države - Republike i Napuljske kraljevine od sredine XVII do početka XIX stoljeća, Naše more, year XXXII, No. 5-6, Dubrovnik: 261-264.

145. Mitić, I. 1986. Prilog proučavanju odnosa Napuljske Kraljevine - Kraljevine Dviju Sicilija i Dubrovačke Republike od sredine XVII. do početka XIX. stoljeća, Radovi, Vol. 19, Sveučilište u Zagrebu - Institut za hrvatsku povijest, Zagreb: 101-132.

146. Mitić, I. 1987. Kada se Dubrovnik počeo nazivati Republikom, Pomorski zbornik 25, Rijeka: 487-489, 492.

147. Mitić, I. 2004. Dubrovačka država u međunarodnoj zajednici (od 1358. do 1815.), Nakladni zavod Matice hrvatske, Zagreb: 103-104.

148. Mollat du Jourdin, M. 1993. Europe and the Sea, Blackwell Publishers, Oxford (UK) - Cambridge (USA): 205, 207.

149. Muljačić, Ž. 1956. Prve vijesti o busolama na dubrovačkim brodovima, Naše more, year III, No. 5-6, Dubrovnik: 355.

150. Muljačić, Ž. 1965. "Ploviti na dubrovački način", Pomorski zbornik, Book 3, Zadar: 729.

151. Muljačić, Ž. 2006a. Prve vijesti o busolama na dubrovačkim brodovima, in: Iz dubrovačke prošlosti, Matica hrvatska, Zagreb: 91.

152. Muljačić, Ž. 2006b. "Ploviti na dubrovački način", in: Iz dubrovačke prošlosti, Matica hrvatska, Zagreb: 186.

153. Novak, G. 1950. Dubrovačko pomorstvo od svojih početaka do propasti Republike, Dubrovački festival, (Dubrovnik, 8.-21. IX.), Tisak "Tipografija”, Grafičko-nakladni zavod - Zagreb, Dubrovnik; 55, 59.

154. Novak, G. 2004a. Jadransko more u sukobima i borbama kroz stoljeća (The Adriatic Sea in conflicts and battles through the centuries), Od 1409. godine do Drugog svjetskog rata, Vol. II, Marjan tisak, Split: 14.

155. Novak, G. 2004b. Prošlost Dalmacije, Book I, Marjan tisak, Split: 149.

156. Novak, V. 1953. Učešće dubrovačke flote u španskoj Nepobedivoj armadi, Zgodovinski časopis, 
(Kosov zbornik), Vol. VI-VII, (1952-1953), Ljubljana: 604-611.

157. Orešković, L. 2000. Luj XIV. i Hrvati, Neostvareni savez, Dom i svijet, Zagreb: 178, 181, 183, 187, 189, 233.

158. Parker, G. 2001. The military revolution, Military innovation and the rise of the West 1500-1800, Cambridge University Press, Cambridge: 100.

159. Pavlić, A. 1907. Tristota obljetnica smrti Miha Pracata, (I. Njegov testament/His Last Will), Srd, year VI, No. 1, 2, 3, 5, Dubrovnik: 36, (73-80), (118-125), (226-233).

160. Pederin, I. 1981-1982. Gospodarski i ideološki pristup uskočkom ratu i uskočkom mitu, (Economic and Ideological approach towards Uskoks' War and the Uskok's myth), Senjski zbornik, year IX, Senj: 184-190, 192, 197.

161. Pederin, I. 1990. Mletačka uprava, privreda i politika u Dalmaciji (1409-1797), Review "Dubrovnik", Biblioteka "D” - Znanost, Book 17, Dubrovnik: 165.

162. Pederin, I. 1996. Jadranska Hrvatska u povijesti staroga europskog bankarstva, Književni krug, Split: 197.

163. Phillips, C. R. 1992. Six Galleons for the King of Spain, Johns Hopkins University Press, Baltimore-London: 189.

164. Pierucci, P. 2001. Vrata prema Istoku, Dubrovačka kovnica novca (17.-18. st.), PGM Ragusa, Dubrovnik: 30, 37, 60 .

165. Polić-Bobić, M. 1986. Prilog utvrđivanju podataka za cjelovitu biografiju Vice Bune, Radovi, vol. 19, Sveučilište u Zagrebu - Institut za hrvatsku povijest, Zagreb: 224-225.

166. Polić Bobić, M. 2000. Među križom i polumjesecom, Dubrovačke dojave španjolskome dvoru o Turcima u XVI. stoljeću, Naklada Ljevak, Zagreb: 126, 143-144.

167. Popović, T. 1988a. Izvoz ribe i koral[j]a u XVI veku, Istorijski časopis (Revue Historique), Book (Livre) XXXV, Istorijski institut (Institut D'Histoire), Beograd: 41-44.

168. Popović, T. 1988b. Izvoz balkanskog krzna u XVI veku, Istorijski časopis (Revue Historique), Book. (Livre) XXXV, Istorijski institut (Institut D’Histoire), Beograd: 45-46, 48, 50-52.

169. Pribojević, V. 1991. O podrijetlu i zgodama Slavena, Književni krug, Split: 77-78.

170. Prijatelj, Kruno, 1995. Kroz povijest umjetnosti u Dalmaciji (XIII-XIX. st.), Studije i sinteze, Književni krug, Split: 233-234.

171. Putanec, V. 1952. Onomastički prinosi na temelju mletačke kronike Martina da Canal, Anali Historijskog instituta u Dubrovniku, year, Vol. I, Dubrovnik: 171-172.

172. Raukar, T. 1977. Venecija i ekonomski razvoj Dalmacije u XV i XVI stoljeću, Radovi Instituta za hrvatsku povijest, 10, Sveučilište u Zagrebu, Zagreb: 212-213.

173. Ray Martin, L. 2001. The Art and Archaeology of Venetian Ships and Boats, Chatham Publishing, London: 256.

174. Rešetar, M. 1908. Dubrovački brod XVI. vijeka, Dubrovnik, (Weekly Newspaper), year XVII, No. 13, Dubrovnik: 1-2.

175. Rešetar, M. 1922. Kulturne sličice iz Dubrovnika srednjeg vijeka, Jugosloven, year I, No. 28, (Nov. $\left.25^{\text {th }}, 1922.\right)$, Dubrovnik: 2.

176. Romano, R. 1962. Per una valutazione della flotta mercantile Europea alla fine del secolo XVIIIe, Studi in onore di Amintore Fanfani, Vol. V, Firenze: 573-591.

177. Rožman-Kandido, M. 1990. Francuski putopisi kroz Dalmaciju od prvog križarskog pohoda do kraja XVIII stoljeća, Mogućnosti, year XXXVII, No. 11, 12, Split: 1160, 1165, 1168; 1415-1416.

178. Statut grada Dubrovnika 1272. (translation: Mate Križman and Josip Kolanović), Historijski arhiv Dubrovnik, Dubrovnik, 1990: 199, 422.

179. Stanojević, G. 1973. Senjski uskoci, Vojnoizdavački zavod, (Vojna štamparija - Split), Beograd: 74, 239.

180. Statut grada Dubrovnika: sastavljen godine 1272 (based on critical issues of the text in Latin by B. Bogišić andi K. Jireček translated into Croatian by A. Šoljić, Z. Šundrica and I. Veselić; introductory study witten by Nella Lonza), Dubrovnik: Državni arhiv u Dubrovniku, 2002.

181. Stojan, S. 2007. Oporuke "Trista Vica udovica": iz lopudske svakodnevnice u drugoj polovici 16. stoljeća, Anali Zavoda za povijesne znanosti HAZU u Dubrovniku, Vol. XLV, Zagreb - Dubrovnik: 195, 199-200.

182. Stradling, R. A. 1992. (2003). The Armada of Flanders, Spanish Maritime Policy and European War, 1568-1668, Cambridge University Press, London: 88-89, 106-108, 114-115.

183. Stulli, B. 1952. Ordines artis nauticae secundum consuetudinem civitatis Ragusii, Jedna zbirka 
pomorskog zakonodavstva Dubrovačke Republike iz god. 1557., Anali Historijskog instituta u Dubrovniku, year I, Vol. I, Dubrovnik: 99, 101.

184. Stulli, B. 1989. Povijest Dubrovačke Republike, Dubrovnik-Zagreb: 46.

185. Stulli, B. 2001. Dubrovačka Republika u XV. i XVI. stoljeću, in: Studije iz povijesti Dubrovnika, Konzor, Zagreb: 13.

186. Šerović, P. D. 1926. Španjolska mornarica i naši pomorci u prošlosti, Jadranska straža, year IV, No. 11, Split: 250.

187. Šišević, I. 1959. Argosy, Pomorstvo, year XIV, No. 9, Rijeka: 348.

188. Šišević, I. 1989. Dubrovačko pomorstvo u knjizi Mediteran i mediteranski svijet u vrijeme Filipa II, Dubrovnik, (Review for culture), year XXXII, No. 1-2, Dubrovnik: 156.

189. Škrivanić, G. A. 1960. Koronelijevi podaci o Dubrovačkoj Republici i o njegovoj izradi karte republike, Istoriski časopis, (Revue Historique), Book IX-X, (1959), Beograd: 200.

190. Šundrica, Z. Dubrovačko pomorsko pravo, Translation of Book VII of the Statute of Ragusa (on the $700^{\text {th }}$ anniversary of its codification) 1272-1972, Dubrovnik, 1972: 26.

191. Tadić, J. 1925. Dubrovački nadbiskup - veliki prijatelj i uhoda Francuza, Trivulzio (1521-1543), Novo doba, year VII, No. 314, (Dec 24 ${ }^{\text {th }}$, 1925.), Split: 14.

192. Tadić, J. 1928a. Dubrovnik u prošlosti i sadašnjosti, Stari i novi Dubrovnik, Naši gradovi na moru, (Reprinted from "Nova Evropa", Book XVII), Zagreb: 8-9.

193. Tadić, J. 1928b. Iz starog Dubrovnika, Dubrovački zabavnik, (Calendar of Bookshop and Printing-house "Jadran"), Dubrovnik: 43-44, 46.

194. Tadić, J. 1928c. Uskoci i Dubrovnik, Jadranska straža, year VI, No. 9, Split: 269-271.

195. Tadić, J. 1928d. Vice Stijepović-Skočibuha, trgovac i pomorac (1534-1588), Novo doba, year X, (Dec $\left.24^{\text {th }}, 1928\right)$, Split: 22.

196. T. J. [Tadić J.] 1929a. Dubrovčani i bitka kod Lepanta, Dubrovnik, (Illustrated monthly review), year I, No. 2, Dubrovnik: 76-77.

197. Tadić, J. 1929b. Prilozi istoriji dubrovačkog pomorstva, (I. Dubrovačko-engleska trgovina u XVI. stoleću), Jadranska straža, year VII, No. 6, Split: 164-165.

198. Tadić, J. 1929c. Prilozi istoriji dubrovačkog pomorstva, (II. Putovanja i račun jedne dubrovačke lađe), Jadranska straža, year VII, No. 6, Split: 165-167.

199. Tadić, J. 1929d. Prilozi istoriji dubrovačkog pomorstva, (III. Kmetovi-mornari), Jadranska straža, year VII, No. 6, Split: 167-168.

200. Tadić, J. 1929e. Prilozi istoriji dubrovačkog pomorstva, (Gusari), Jadranska straža, year VII, No. 9, Split: 250-253.

201. Tadić, J. 1931a. Dva pisma o Magelanovom putovanju, Jadranska straža, year IX, No. 9, Split: 239-240.

202. Tadić, J. 1931b. Pogibija uskočkog vodje Djura Daničića 1571, Prema dokumentima iz Arhiva Dubrovačke Republike, Novosti, year XXV, (Jan 23d, 1931), Zagreb: 8.

203. Tadić, J. 1931c. Pogibija uskočkog vodje Djura Daničića 1571, Novosti, year XXV, (Jan 24 ${ }^{\text {th }}$, 1931), Zagreb: 8.

204. Tadić, J. 1932. Španija i Dubrovnik u XVI v., Posebna izdanja, Vol. XCIII, Društveni i istoriski spisi, Book 41, SKA, Beograd: 121-122.

205. Tadić, J. 1933a. Miho Pracatović-Pracat, Dubrovnik: 5, 14, 34-35, 50-55.

206. Tadić, J. 1933b. Tendeciozni prikaz knjige o Mihu Pracatu, Odgovor g. Don Vicku Lisičaru, Novi Dubrovnik, year I, No. 2-3, (Sept.), Dubrovnik: 29-30.

207. Tadić, J. 1936a. Djeca na brodovima starih Dubrovčana, Naš mornar, (Illustrated calendar of Jadranska straža), year IX, Published by Izvršni odbor Jadranske Straže u Splitu, Hrvatska štamparija Stjepan Vidović, Split: 68-69.

208. Tadić, J. 1936b. Uskoci i Dubrovnik u XVII vijeku, Novosti, year XXX, No. 19, (Sunday, January $\left.19^{\text {th }}, 1936\right)$, Zagreb: 13.

209. Tadić, J. 1937a. Francusko-turski savez 1536. g., Francusko-turski odnosi početkom XVI. vijeka, Jadranska straža, year XV, No. 9, Split: 360-361.

210. Tadić, J. 1937b. Dubrovčanin Saro Gučetić francuski diplomat, Jadranska straža, year XV, No. 11, Split: 453-454.

211. Tadić, J. 1938a. Dubrovčanin Serafin Gučetić, francuski diplomat (1496-1547), (Reprinted from "Jadranska straža" No. 9, 11, 12, year 1937. and No. 1 i 2, year 1938.), Hrvatska narodna tiskara Stjepan Vidović, Split: 18, 23, 38 . 
212. Tadić, J. 1938b. Francusko-turski savez 1536. godine, (Franco-Turkish alliance 1536), Jadranska straža, year XVI, No. 1, Split: 17.

213. Tadić, J. 1938c. Francusko-turski savez 1536. godine, Jadranska straža, year XVI, No. 2, Split: 61.

214. Tadić, J. 1948. Dubrovački portreti, I, Beograd: 207, 233.

215. Tadić, J. 1949. Organizacija dubrovačkog pomorstva u XVI veku, Istoriski časopis, (Revue Historique), year I, Vol. 1-2 (1948), SAN, Beograd: 8-11, (n. 30), 13, (n. 38).

216. Tadić, J. 1952a. O pomorstvu Dubrovnika u XVI i XVII veku, Dubrovačko pomorstvo, (Zbornik), Dubrovnik: 175, 179-180.

217. Tadić, J. 1952b. O pomorstvu starog Dubrovnika, Nova trgovina, 1, Beograd: 57.

218. Tadić, J. 1962. Ragusa e il suo porto nel Cinquecento, Per una storia delle relazioni tra le due sponde adriatiche, Quaderni dell' Archivio Storico Pugliese, 7, Società di Storia Patria per la Puglia, Bari: 106.

219. Tadić, J. 1971. Istorija Dubrovnika do polovine XV veka, Istorijski časopis (Revue Historique), Book XVIII, Istorijski institut (Institut d'histoire a Beograd), Beograd: 38.

220. Tenenti, A. - Tenenti, B. 1985. Il prezzo del rischio, L'assicurazione mediterranea vista da Ragusa (1563-1591), Jouvence, Roma: 72, 159-160.

221. Torbarina, J. 1933. Argosy ili: šta engleski rečnik duguje Dubrovniku (Argosy or: What does the English dictionary owe to Ragusa), Nova Evropa, Vol. XXVI, No. 5, (May 26 $6^{\text {th }}, 1933$.), Zagreb: 223.

222. Vekarić, S. 1954. Dubrovačka trgovačka flota 1599. godine, Anali Historijskog instituta JAZU u Dubrovniku, year III, Dubrovnik: 427-430.

223. Vekarić, S. - Vekarić, N. 1987. Tri stoljeća pelješkog brodarstva (1600-1900) / Three Centuries of Pelješac Shipping (1600-1900), Pelješki zbornik, 4, Zagreb: 12, note 6.

224. Vekarić, S. 1997. 300 godina pelješkog brodarstva duge plovidbe, in: Naši jedrenjaci, Pomorska biblioteka 1, Književni krug, Split: 267, note 6.

225. Vidović, R. 1984. Pomorski rječnik, Logos, Split: 205.

226. Villari, L. 1904. The Republic of Ragusa, An Episode of the Turkish Conquest, J. M. Dent \& Co., London: 86-87.

227. Vinaver, V. 1953. Trgovina bosanskim robljem tokom XIV veka u Dubrovniku, Anali Historijskog instituta u Dubrovniku, year II, Dubrovnik: 127.

228. Vinaver, V. 1955. Crno roblje u starom Dubrovniku (1400-1600), Istoriski časopis, (Revue Historique), Book. (Livre) V, (1954-1955), Beograd, SAN: 437-438, 440-441.

229. Vinaver, V. 1956. Dubrovačka nova ekonomska politika početkom XVII. veka, Anali Historijskog instituta JAZU u Dubrovniku, year IV-V, (1955-1956), Dubrovnik: 430, n. 24.

230. Vinski, I. 1975. Problemi procjene gospodarske moći Dubrovačke Republike, Mogućnosti, year XXII, No. 5, Split: 553-554.

231. Voje, I. 1977. Ekonomske veze između Dubrovnika i Dalmacije u XV stoljeću, Radovi Instituta za hrvatsku povijest, 10, Sveučilište u Zagrebu, Zagreb: 382.

232. Vučetić, A. 1896. Dubrovnik za Kandijskog rata 1645-1699, Iz dopisivanja Republike sa M. Sorgom-Bobalijem, (Preštampano iz gimnazijskih programa od 1894-95. i 1895-96. g. / Reprinted from Grammar School programmes from 1894-95 and 1895-96), Nakladom Spisateljevom / published by the author, Tip. D. Pretnera, Dubrovnik: 13, 19-20, 25.

233. Vučetić, A. 1907. Miho Pracat najveći dubrovački bogataš i dobrotvor, Srđ, year VI, No. 15, 16, 17, 18, 19, 22, Dubrovnik: 700-707, 750-753, 797-800, 841-845, 894-898, 1036-1040.

234. Vučetić, A. 1913. Un'escursione di Pietro Zrini in Dalmazia nel 1654, A spese della R. Deputazione, Venezia: 10, 12.

235. Zlatar, Z. 2007. Udio vlastele u dubrovačkoj kreditnoj trgovini (1520-1623): kvantitativna analiza vjerovnika, Anali Zavoda za povijesne znanosti HAZU u Dubrovniku, Vol. XLV, Zagreb - Dubrovnik: 132 . 
Đivo Bašić

\title{
Dubrovačko pomorstvo od XV. do XVII. stoljeća
}

\begin{abstract}
Sažetak
Pomorska i kopnena trgovina grada Dubrovnika i njegove okolice činila je "temeljno kamenje" na kojima je izidana dubrovačka veličina, njegova političko-ekonomska snaga i kultura. Još 1441. se smatralo da dubrovačku trgovinu čini 3/4 pomorska, a samo 1/4 kopnena trgovina. U Dubrovniku se prvi put 1181. spominje općina (comunitas ragusina), te vremenom (p)ostaje grad-država. Dubrovačkom Republikom počinje se nazivati oko 1430. godine. Sve do sutona Dubrovačke Republike (1806.), za Dubrovnik je vrijedio ugovor sklopljen s Turskom 1442. godine. Dubrovčanima je pogodovalo što tada u susjedstvu imaju jednog vladara i državu, a ne više njih svojeglavih i učestalo obijesnih. Kartograf Vincenzo Coronelli u djelu "Mari, Golfi, Isole, ...” (1688.) kaže za Dubrovčane: “...Najsigurniji su branitelji svoje slobode i ulažu sve snage da je očuvaju, mrzeći pritom bilo kakav oblik ropstva...". Dubrovačke brodove napadaju gusari s Rodosa 1507.-1509. i kasnije. Glavni uzrok procvata dubrovačkog pomorstva i trgovine temeljio se na usredotočenosti javnog života na te domene. Dubrovačka Republika ovisila je o ulaganju u pomorstvo i pružanju pomoći poticaja, međudjelovanju silnica i susljednom (p)ojačanju vlastitog prosperiteta (svojih obogaćenih građana). Dubrovački pomorski zakon o osiguranju (Ordo super assecuratoribus) od 5. ožujka 1568. najstariji je u svijetu, tako da je više od stoljeća stariji od zakonskih propisa o pomorskom osiguranju Ordonnance de la marine iz 1681. godine. Osim glavnog brodogradilišta u staroj luci Dubrovnika (starom gradu - in portu interiori Ragusii, in portu Ragusii), do gradnje velikog brodogradilišta u Gružu (1526.), još u XIV. stoljeću postojala su brodogradilišta u Stonu, te na obližnjim otocima Lopudu, Šipanu (Suđurađ) i Koločepu (Kalamoti). Paladije Fusko (1450.-1520.) u svom djelu De situ orae Illyrici (postumno tiskanom 1540.) kaže “da nema tako zabitna i došljacima tako nepristupačna dijela Europe gdje nećeš naići na Dubrovčane kako trguju”. Dubrovnik je, po nekim istraživačima, u XIV. stoljeću bio treći na Sredozemlju (iza Genove i Venecije). U XVI. stoljeću Dubrovačka Republika je prva na Sredozemlju, te po prekooceanskim trgovačkim jedrenjacima dubrovačke i strane zastave treća na svijetu (iza Spanjolske i Nizozemske). Bartolomeo Crescentio u djelu Nautica Mediterranea (Roma, 1602, str. 4-5) kaže: “...od stručnjaka i majstora za galijune najbrojniji, a valjda i najsposobniji su u ovom (Sredozemnom, op. a.) moru Dubrovčani”, a Pantero Pantera u djelu L'Armata Navale (Roma, 1614, str. 66) zapisuje: “...dok su za gradnju nava i galijuna visoko poštovani majstori iz Dubrovnika, Portugala i Engleske"."Argosy" u biti znači "dubrovačka lađa". Mnoga pregnuća i dostignuća u području brodograditeljskog umijeća izdižu istočnu obalu Jadrana nad onom zapadnom, jer je prečesto bila put uspjeha kojim su i brodovi i ljudi doticali različite dijelove svijeta.
\end{abstract}

Ključne riječi: Pomorstvo, Dubrovnik (Ragusa), Dubrovačka Republika, Republika Sv. Vlaha, Dubrovački pomorski zakon 